\title{
Lilla Daam. Kogukonna usundiline muistend kui homogeenne tervik
}

\author{
$\underline{\text { Eda Kalmre }}$
}

Viimasel kümnendil on Eesti meedias maad võtnud üleloomulike nähtuste kujutamine millegi reaalsetena, mis meie ellu loomupäraseina kuuluvad ja milles isegi ei kahelda. Oma kummituselamusi vahendavad meedias üldsusele tuntud inimesed: näitlejad, ajakirjanikud, kirjanikud ja kunstnikud. Kinnisvaramaaklerid räägivad, kuidas nad on raskustes nende korterite müümisega, kus keegi on tapetud, ja missuguste abinõudega nende kliendid «mõõdavad» kummituse olemasolu ruumis. Sensitiivid pakuvad välja nippe kooseluks vaimuga. $\underline{1}$ Kõrvuti on fiktsioon ja konkreetsus: isikud, kohad ning (õnnetus)juhtumid.

Folkloristikas räägitakse tänapäeval vaimulugudest kui eraldi zhanrist, mis on populaarne noorte hulgas. Läti folklorist, vaimulugude uurija Guntis Pakalns väidab, et igal ajal on niisugused lood olemas olnud ja mitte ainult üksikute lobisemishimuliste jutuna, vaid inimestele eluliselt vajaliku teemana, mis sügavalt puudutab meie emotsioone ja maailmapilti. Niisuguste lugude kõrgaeg meedias saabus 1990. aastatel koos muutustega ühiskonnakorras ja ideoloogias. (Pakalns 1995: 1). Rootsi kaasaegse muistendi uurija Bengt af Klintberg konstateerib, et vaimu- ja kummituslood on tänapäeval elujõulised, hoolimata faktist, et neid ei toeta tänapäeva moodne maailmavaade; nende esmaseks funktsiooniks on meelelahutuse pakkumine, oma olemuselt toetuvad nad hirmule ja surma fenomeni ajatule olemasolule (Klintberg 1989: 87). Nii või teisiti, suulises traditsioonis on kummitus- ja vaimulood ajast sõltumatult, kas siis muistenditena või isiklike üleloomulike kogemustena, stabiilselt ja konservatiivselt alati oma rolli hoidnud. Üleloomulike kogemuste tundmine ja nendest rääkimine tänapäeva ühiskonnas tähendab omamoodi materiaalse ja vaimse poole tasakaalustamist. Gillian Bennett arvab oma uurimuses üleloomulikest kogemustest lähedase inimese kaotusega seoses, et inimestel on kogemusi, mis nõuavad selliseid seletusi, mida tänapäeva teadus ei suuda pakkuda, ja nad ise vajavad midagi rohkemat kui lihtsalt materialistlikke seletusi. Meie ametlik kultuur ja rahvapärimus ei rahulda neid vajadusi adekvaatselt. Nii pöördutaksegi seletuste otsingul mitteametlike kanalite - New Age'i ja alternatiivusundite poole, aga tavaliselt tekitatakse interaktiivsel suhtlemisel (oma) usundisüsteem. Läbi folkloori loodud traditsionaalsuse pakuvad nad üksteisele isikukogemusel põhinevaid jutte, diskussioone ja ideede vahetust. (Bennett 1999: 2).

Meedia avaldab vaimu- ja kummituslugusid eelkõige meelelahutuseks, aga samas mõjutab nende kaudu ka lugejate-jutustajate repertuaari, pakkudes popkultuurist, kirjandusest, kunstist ja alternatiivusunditest laenatud temaatikat ja motiive ning kinnitades nii omal kombel usku üleloomulikku. Suuliselt esitatuna ja mutimeedilise eksistentsi kaudu saavad need lood osaks meie üldisest kultuurikontekstist. Nii kuuluvad lood vaimudest ja kummitustest jätkuvalt ka 21. sajandi inimeste argiellu. Muidugi suhtuvad tänapäeva inimesed üleloomulikesse lugudesse teatava skeptitsismiga. Statistika näitab aga, et see osa inimesi, kes vaimude või kummituste olemasolu ainult kohvilauahuumoriks peavad, ei olegi suurem sellest teisest hulgast, kellel on olnud oma isiklik kogemus või kes kummituse olemasolu võimalikuks peavad. Leea Virtanen küsitles töötajaid ja õppureid ühes Helsingi ülikooli hoones, kus kummitas. Viiekümnest küsitletust 20\%-l oli oma kummituselamus (nad olid näinud või kuulnud majas midagi üleloomulikku), 50\%-l ei olnud oma isiklikke kummituselamusi, aga nad pidasid nende olemasolu võimalikuks; vaid 30\% suhtusid kummituse olemasolusse skeptiliselt ja pidasid neid jutte ainult kohvilauahuumoriks. (Virtanen 1991: 415). Kuna paljud on ise kogenud üleloomulikku, siis on inimestel üldiselt kalduvus pigemini uskuda kummituse olemasolu. Seda on konstateerinud teisedki kummituslugude uurijad. (Vt Montell 1992: 89-90). 
Epp Väljaotsa artiklis ühe sensitiivi poolt pakutud populaarne skeem, et üleloomulike nähtuste olemasolu majas on otseses seoses valdkonnaga, millega seal tegeldakse, oleks justkui pärit TV-filmist «Tondipüüdjad». $\underline{2}$ «On teatud kohti, kuhu energia tasapisi koguneb ja seal siis ennast liigutama hakkab. Kõik muuseumitöötajad on ühte meelt: usuvad tonte. Koos vanaaegsete asjadega on kantud muuseumidesse kokku ka vanade aegade energiat» (Väljaots 1999: 18). Uskuda või mitte, aga tõepoolest millegi poolest ebatavalised kohad ja erilised hooned soodustavad kummitusjuttude teket ja levimist. Folklorist Patrick B. Mullen kirjutab, et kogu maailmas on paljud kummitava maja muistendid ilmselt tekkinud mõne ebatavalise tunnuse või seletamatu fenomeni tõttu. Ta toob näiteks konkreetse valge maja Indianas, millel on unikaalne arhitektuuriline disain ja milles ei ole keegi kunagi elanud. Nendest faktidest oli küllalt, et «üles ehitada» muistendit mõrvarist või õnnetusest, mis oletatavasti selles majas aset leidis. (Mullen 1972: 104; vt ka Mitchell 1969: 97-98). Kummitavate kohtade kohta tehtud statistika näitab ka seda, et kummituse ilmumine on pooltel juhtudel nagunii seotud maja või kindla osaga sellest. (vt Montell 1992: 91-92).

Kirjandusmuuseumi vanas majas, kus ma 1978. aastast peale töötan, elab juba kaheksa kümnendit lugu neiust, kes õnnetu armastuse pärast vabasurma läks ja pärast seda kuidagi rahu ei saa. Ta ilmutab end aeg-ajalt maja asukatele ja tema tegutsemise tagajärjeks arvatakse naljatamisi paljud majas juhtunud ebatavalised asjad. Lugu ise on niivõrd triviaalne ja kirjanduses tuntud, et tundub, klassikalisemat usundilist muistendit on raske välja pakkuda. Selle muistendi ja teiste niisuguste üleloomulike lugude aluseks oleva kummitus- ja vaimukujutelma vanus on tegelikult ainult mõned sajandid ja see kinnistuski ilmselt eelkõige tänu vastavasisulistele rahvaraamatutele. $\underline{3}$ Nii on ka usundilised muistendid kummitavatest majadest suhteliselt hiline nähtus folklooris ja neid on peetud tänapäeval rohkem linnafolkloori hulka

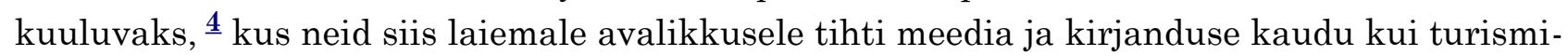
objekti tutvustatakse.

Kirjandusmuuseumi kummitusjutu puhul on tegemist konkreetse kohaga seotud looga, mille hoidjaks ja levitajaks on olnud üks küllaltki väike ja eriline kogukond, Vanemuise 42 töötajad: enamuses folkloristid, bibliograafid, kirjandusloolased ja majanduspersonal (valvurid, helitehnikud, koristajad, restauraatorid jt) ning maja külastavad uurijad ja üliõpilased. Intervjueerisin üle kolmekümne selle maja praeguse ja endise töötaja, kusjuures intervjuudes olin ka ise osaline tavapärasest rohkem, kuna tegemist oli ühiselt vallatava informatsiooniga. Küsitlesin lugu ennast (kuidas/millisena seda teatakse), püüdsin nende jutustuste kaudu jälgida selle arengut ja arendusi, üksikisiku ja kollektiivi osa selles protsessis, võimalikke isiklikke auditiivseid ja visuaalseid kontakte majas (müra, sammud, kummitusenägemised jm) seoses selle looga, loo tähtsust jutustaja arvates. Püüdsin jälgida ka seda, kes kellele ja millal on seda vahendanud, missugustes situatsioonides ning kuidas kasutanud jne. $\underline{\mathbf{5}}$

\section{Muistendi kujunemisest ehk pärimus pärimusest}

Jutu põhiliini kujunemine toimus arvatavasti 1920. aastatel. Nagu tüüpilise muistendi puhul ikka, toetub see lähiajale, tegelikult elanud isikutele ja konkreetsele kohale. Kuivõrd pärimus vastab reaalselt asetleidnule, seda on püütud hiljem ajaloo materjalide põhjal tuvastada. $\underline{\mathbf{6}}$

Loo teadaolevad reaalid viivad meid 19. sajandi viimase kümnendi lõpus ehitatud hilisbarokkstiilis siseinterjööriga majja (praeguse Kirjandusmuuseumi kõige vanem osa), mis kuulus saksa perekond von Grotele, kellel oli viis tütart. Onnetut armastuslugu on tagantjärgi seostatud vanuselt kolmanda tütre Frederike Julie Annette Mariega, kes kolmekümneaastaselt (1913. aastal) suri. Tema varajane surm oli väidetavalt ümbritsetud salapäraga, mida perekond siivsalt hoidis. Frederike isikuga seostatigi hiljem juttudes salapärast kummitavat Lillat Daami, kes õnnetu armastuse pärast (ühe levinuma versiooni järgi Mellini kliiniku arsti vastu), 
oletatavasti ise oma elule otsa tegi. Teised õed ja pereliikmed lahkusid Saksamaale 1919. aastal. Pärast seda oli maja eestlase Johann Posti valduses ja pärast tolle surma päris maja tema poeg. Sel ajal üürisid majas ruume korporatsioon Fraternitas Estica ja 2. jalaväerügemendi staap. Alalised elanikud sai maja 1924. aastal, kui siia kolisid üksteise järel Eesti Rahva Muuseumi arhiivraamatukogu, bibliograafia kartoteegid ja rahvaluule arhiiv.

Maja oli suur ja selles olid pikad pimedad koridorid ning keldriruumid. Tihti töötati hilisõhtuti. Sellel ajal hakati ilmselt rääkima ka igasuguseid jutte maja endiste asukate ja kummaliste nägemuste kohta. Praegu teadaolevalt jõudis laiema avalikkuse ette lugu sellest, et muuseumis kummitab, ajakirjanduse vahendusel 1930. aastatel. Artikkel «E.R.A. blond kummitus» ilmus ajalehes "Vaba Maa» 3. veebruaril 1936. aastal (vt lisa 1). See artikkel on praegu üldiselt teadaolev kirjalik allikas, kust on aeg-ajalt kontrollitud jutu süzheed, millest on tehtud koopiaid ja mis on olnud alusmaterjaliks hilisematele ajaleheversioonidele. $\underline{7}$ "Vaba Maa» artikli algusse on põimitud rohkesti üksikasju, maja töötajate nimesid, kes kõik midagi ebaharilikku nägid, siis järgneb lugu sellest, kuidas muuseumi raamatupidaja Ernst Lintsi kummitusega kokku puutus, edasi kummituse oletatav "saamislugu» ja lõpuks on loole lisatud teade hiljuti toimunud maja asjaajaja härra Eisenschmidti enesetapust. Majas kauem töötanud inimesed teavad, et selle artikli taga on üks maja töötaja, raamatupidaja Ernst Lintsi ja ajalehelugu sarnaneb kirjeldatud üksikasjade ja struktuuri poolest üsnagi variandiga, mille Lintsi kuuskümmend aastat hiljem, oma 95. sünnipäeval, küsitlejatele rääkis (vt lisa 2 , intervjuu Ernst Lintsiga). Mitteametlikult (kui lindistamine oli lõpetatud) tunnistas Lintsi üles, et oli kogu selle loo välja mõelnud.

Ja siis oli Lintsi juba pensionil ja ikka oieti vana. Ja siis läksime meie ükskord makiga, et las tema räägib selle loo sinna maki peale ka. Ja tema rääkis. Nii. Ja kõik. Siis, kui makk oli kinni pandud ja tema tuli meid oue saatma, siis kui tema veendus, et see ei lähe mitte kuskile lindi peale, siis seal oues jumalaga jättes rääkis tema minule hoopis teise loo. Ja rääkis niiviisi, et temal oli sõber, üks Postimehe ajakirjanik, kellel oli oudselt raha vaja. Ja et tema saaks nü̈̈ niisuguse artikli kirjutada, mis noh tingimata läheks ja oleks loetav

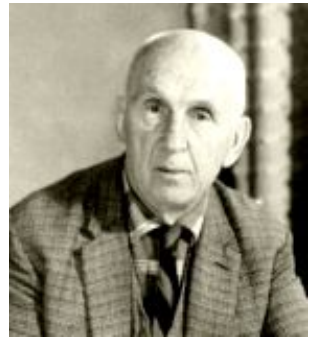
ja nõnda edasi, siis tema selle sõbra aitamise pärast rääkis niisuguse jutu. Mina ei ole seda Lintsi käest lindi peale saanud. (Intervjuu nr 27)

See, et Lintsi oleks kogu loo, mis tookord ajalehes ilmus, ainuisikuliselt välja mõelnud, ei ole minu arvates usutav, pigem oli temapoolne panus ainuüksi tema enda poolt filigraanselt kujundatud kummituse nägemise lugu, mis on tõesti räägitud uskumiseks ja sisaldab paljusid fakte ja nimesid, mis ajaleheartikli ja tema enda vahendusel majas vähesel määral tuntud on. Arvamus, mille käis välja teine tol korral Lintsit intervjueerinud kolleeg, tundub õigem olevat.

Ja siis ajasime me tema käest välja selle, et noh see on niisama luuletatud lugu, et kellelgi ta sõpradest oli raha vaja ja tahtis kirjutada. Ja igasuguseid asju muidugi majas juhtus, kõik nägid ja tema muudkui rääkis ka ikka et on ... ja kuna siin oli terve hulk inimesi, kes ilmatupalju kartsid pimedates keldrites noh. Ma ei tea, kas siis päris alguses oli elekter või ei olnud nendes keldrites. (Intervjuu $\mathrm{nr} 2$ )

Sama versiooni kinnitavad kaks kirjalikku teksti Eesti Rahvaluule Arhiivist. Paul Ariste, tolleaegne noor ERA töötaja, on 1927. aastal justkui iseenda teadmistele tuginedes üles kirjutanud niisuguse loo: 
Tartus Eesti Rahva Muuseumi ruumes Aia 42 käivat keegi ringi. Ametnik prl. Helene Treial teadis jutustada, et oppetaja Laur, kes suri mõne aasta eest, liikuvat sääl ringi. Tollal oli sääl korporatsioon "Estica» konvent, kui Laur suri. Laur oli "Estica» liige. Koolnu peeti mõne aja konventi ruumes lautsil. Ö̈̈si valvand 6 kaasvõitlejat küünlatule valgel. Äkki kustund kõik kü̈̈nlad. Mehed pole osand hirmuga sü̈̈data elektert põlema. Kui viimaks valgust saadud, olnud mehi viis. Üks

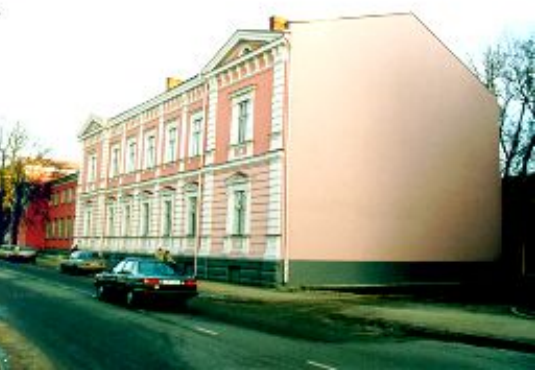
olnud kadund. Viimaks leitud toogi nurgast kapi takka. Sinna pääsnud vaid ülevalt kapi otsast. Kuidas mees sai sellega hakkama ei tea. - Praegu on see mees juba vilistlane.

Ka teenija, proua Int usub, et Laur käib sääl ringi. Kord ta käskind oma oel panna lahtised aknad kinni. Õde olnud tükk aega üleval - kuuland mängu. Proua Int läind järgi. Tulnud õega alla, kuuland: ̈̈ks tuleb üleval kojas nende pää kohal. Proua Int hakand oega pragama, et sa lased võoraid poisse sisse, kurameerisid nendega üleval. Õde ajand vastu, et pole kedagi olnud. Läind siis tulega üksikasjalikumalt otsima. Ei ole olnud kippu ega kõppu.

Mitu korda teenija kuulnud, kuidas käidud lugemissaalis ja kantseleis. Asjaajaja Eisenschmidti teenija teind hilja öösi vanni. Läind hoovipoolsesse majja, kus elab asjaajaja. Näind, kuidas maja olnud valge ja sääl sees liikund ilus noormees.

Kord ametnik Lindsi olnud ôhtu hilja töös üksipäini. Äkki näind, kuidas asjaajaja kabinetist tulnud naisterahvas ja läind üle kantselei ahju poole. Härra Lindsi arvanud, et see on teenija õde. Tahtnud veidi hirmutada. Hakand haarama, käte vahele jäänd paljas õhk.

Ametnik prl. Lydia Jossep (Joosep?) arvab, et keegi õnnetult surnud mõisnikupreili liigub muuseumis ringi. (9. XII 1927)

(E 61651/2)

Sellesse küllaltki skemaatilisse üleskirjutusse on liidetud kolm juttu: surnuvalvamine, proua Inti üleloomulikud kogemused (saladuslikud sammud, kummituslik noormees) ja Lintsi kummitusenägemine. Viimased kaks on üsna sarnased sellega, mis «Vabas Maas» ilmus. Ariste üleskirjutus on tehtud ajal, kui asjaajaja Eisenschmidt veel elas (ta laskis enda maha 1929. aastal), ja nii ei ole Ariste üleskirjutuses puudutatud asjaajaja isiku teemat (tema isiklikke üleloomulikke kogemusi ja muidugi tema kui esimese ohvri osa). Ariste üleskirjutuses on kummitajaid mitu, ka ei maini Ariste, kellelt ta kogu jutu üles kirjutas. Selle üleskirjutuse järgi võiks arvata, et niisugused jutud olid majas üldiselt liikvel.

Tõenäoliselt tekkis soodus õhkkond kummitusjuttude levikuks pärast esimest surnut, korporanti, kes 1920. aastate alguses majja lautsile toodi. See juhtus vahetult enne seda, kui maja Eesti Rahva Muuseumi käsutusse läks. Seesama surnuvalvamise jutt on olnud ka Lintsi repertuaaris ja selle on tema suust üles kirjutanud Oskar Loorits. Loo uhke lõpu järgi võib otsustada, et Lintsi oli üsna hea traditsioonitundja.

Kui õpetaja Lauri surnud, siis toodud ta laip "Estica'sse" Aia tn. 42, kus säetud auvahid puusärki valvama. Kord öösel kustund järsku tuled. Kui saadud taas valgust, olnud üks neljast auvahist kadund ja leitud alles hiljem nurgast kapi tagant. Üliõpilane (olevat praegu ülikooli oppejõud) seletand, et ta tundnud, nagu haaranuks keegi teda kraest ja visanuks üle kapi nurka. Kapipäälne olnudki tõepoolest tolmukorraga kaetud ja ilma 
jälgedeta, mis ronimisel pidanuksid paratamatult tulema. Eks siis naiste seas levinudki jutt, et vanakurat tulnud pastori hinge järgi, kuid võtnud pimedas kogemata teise ja visanud selle kapi taha.

\title{
Tartu, 5.II 36 E. Lindsi jutu järgi Oskar Loorits
}

(ERA II 121, 467)

Jutt on üles kirjutatud paar päeva pärast seda, kui ilmus «Vaba Maa» kummituseartikkel. Millegipärast ei kasutata selles artiklis surnuvalvamise lugu üldse, kuigi on teada, et see on olnud samal ajal tuntud. See süzhee on ka hiljem millegipärast kõrvale jäetud ja varsti unustatud. Minu poolt intervjueeritud vanematest kolleegidest ei olnud keegi sellest korporandi valvamise loost kuulnud (ka need, kes Ernst Lintsiga koos töötasid), ainult üks jutustaja mainis seda lõpuks.

\begin{abstract}
Ah soo, veel üks hukkasaamine, üks korporant ju jõi ennast surnuks seal majas ka. Enne seda oli ju maja mingi korporatsiooni käes ja siis seal üks korporant jõi ennast surnuks või ühesõnaga suri ka joomingu käigus seal. Nii et see ka veel üks õnnetu ots, aga ikka mehed ja kõik. Ka niisugust tõlgendust olen ma kuulnud, et näe Lilla Daam nõuab meeste hingi. Et need, kes nü̈d kõik otsa saavad, on kõik mehed. (Intervjuu nr 27)
\end{abstract}

Kõik see kokku võib tähendada ainult seda, et 1920. - 30. aastatel oli niisuguste juttude rääkimise traditsioon majas küllaltki elav ja mitmekülgne, korraga oli käigus mitu erinevat süzheed. 1930. aastate lõpuks oli aga välja kujunenud ja käibele jäänud üks põhilugu: romantiline Lilla Daami lugu, millele esimese ohvri liitmisega "Vaba Maa» artiklis (näis, nagu oleks see ohver lepitanud kodukäija) oli paika pandud ka võimalik edasine arengutee (Lilla Daam ilmutab end meestele, nõuab meesohvreid). Hilisema jutu loogilise arengu järgi oleks võinud surnud korporanti esimeseks ohvriks pidada (nagu pakub ka ainuke korporanti maininud informant), seda ei ole aga hiljem tehtud. Miks, selle kohta võib praegu ainult oletusi teha, kas ei olnud siiski tegemist traagilise surma või õnnetusjuhtumiga või oli põhjus selles, et see juhtus enne ERMi majja kolimist ja püsikollektiivi tekkimist majas. Surnuvalvamise loosse ei olnud ka kätketud piisavalt dramatismi ja dünaamikat, et kogukonna juturepertuaaris edasi kesta. See on oma olemuselt nn valmis jutt, millele jutustajal või kuulajaskonnal on hiljem mingeid motiive või detaile raske juurde lisada. Suhteliselt teine on lugu kummitusjutuga. Selle jutu sisemise loogika järgi on kummitus niisugune olend, kes aeg-ajalt ilmub ja ennast näitab, järelikult on alati olemas võimalus teda näha, kuulda, tajuda. Kummitusjutu ajatust põhjustab pigemini sellesse algselt kodeeritud võimalus: ta on alati olemas meie kõrval. Nii on tal kogukonna jutuna suuremad shansid edasi kesta ja areneda.

\section{Muistendi arenguvormidest}

Muistendi väljatöötamine ja kujundamine on kollektiivne protsess, mis algab indiviidist ja lõpeb kollektiivis ning toimub mitmete väliste ja sisemiste asjaolude koostoimes. Tänapäeva muistendi uurija Bill Ellis väidab, et muistendi elus võib eristada justkui viis erinevat etappi (Ellis 1989: 35-48). Esimene tähendab mingi marginaalse kogemuse, sotsiaalse rahutuse või stressi tekkimist, selle äratundmist indiviidi poolt, aga mitte veel nimetamist. St seda, et kogemus on ära tuntud kui marginaalne, aga ta jääb väljapoole traditsiooni ja talle pole veel nime pandud. Lauri Honko (Honko 1964: 16) kutsub seda jutu eelstaadiumi nuumeniks Linda Dégh ja Andrew Vázsonyi omistavad enam-vähem samad tunnused proto-memoraadile. (vt Dégh \& Vázsonyi 1974) Seda jutueelset staadiumi on hiljem kõige raskem tuvastada, sest nagu väidab Ellis, ei saa me eelnevat kogemust ja hilisemat muistendi sisu üheselt identifitseerida. Muistendi teine ja veidi kergemini tuvastatav etapp on see, kui marginaalne kogemus verbaliseeritakse. Jutustaja pakub sündmust-kogemust tõesena, kirjeldab seda oma sõnadega, mitte küll veel traditsioonipäraselt. Selles staadiumis on rääkija ja kuulaja(d) eriti lähedalt 
seotud: rääkijale on oluline tema kogemuse aktsepteerimine ja sellest osavõtt ning kuulajaskond aitab kaasa jutu kujundamisel, lisades omapoolset lisainformatsiooni ja vaatenurki. Need tekstid võivad olla inkoherentsed, täidetud ebamääraste alguste ja ajavormidega. Sedasama staadiumi on muistendiuurija Jan Brunvand ilmselt pidanud proto-muistendiks, mis tema tõlgenduses tähendab võimalikku algmaterjali muistendi tekkimiseks kõmu või usundi näol (Brunvand 1981: 194). (Jutu kujunemiskäigu selgitamiseks on seda staadiumi fikseerivat teksti otstarbekam lindistada. Tihtilugu on need tekstid aga nii isiklikud, et folkloristikas tekib probleem, kas neid on üldse eetiline jäädvustada.) Kolmas staadium on nn lõpetatud jutt, st jutt vormitakse sobivaks muistendiks. Esitaja vähendab idiosünkraatilisi elemente jutus, kohendab jutu olemasolevate hinnangute ja traditsiooni järgi vormiliselt sobivaks muistendiks. Niisugust resultaati saab korrata, lisada motiive, meelelahutuslikku jms. Muistendi kui eripärase jutu rääkimise funktsioon saab sellega tagatud: rahutus on jagatud, üks ei ole enam üksi. Neljandaks muistendi eksisteerimise etapiks on metonüüm, st jutt on kuulajaskonnale tuntud ja ei vaja enam esitust, jääb kuulajaskonna teadvusse koos sisemise tunnussõnaga, mis on narratiivi tuumaks. Selliseid metonüüme on tänapäeval igal pool, aga nad on väljaspool olijatele läbipaistmatud. Niimoodi käitudes defineerivad nad kogukonna või grupi maailma ja selle piirid. Lõpetatud juttu esitatakse grupis ainult siis, kui kogukonda tuleb uus liige ja on vaja näiteks initsiatsiooni muistendi teadmise kaudu. Sama on konstateerinud ka Mall Hiiemäe Kodavere kihelkonna muistendite esitamise kohta (Hiiemäe 1978: 126). Viiendaks olekuks on muistendi lühikokkuvõte e raport. St muistend on tuntud, kuid mitte enam aja- ja asjakohane, ta ringleb ainult parodeeritud või lühikokkuvõtte vormis, ta on justkui kaotanud oma varasema energia ja muutunud latentseks. (Ellis 1989: 35-48)

Esimesed kolm arengustaadiumi on sisuliselt järjestikused, iga eelnev juhib järgmisele, kuni lõpetatud jutuni. Kaks viimast olekut (grupi teadvuses metonüümina ja lühikokkuvõttena) tähendavad sisuliselt muistendi allakäiku jutuna ja ei ole minu arvates ilmtingimata järjestikused, nad võivad kohad vahetada, hoopis koos esineda või uusi episoode liites olla uute versioonide karkassiks. Kahte esimest olekut ehk tekkeaega ei ole tavaliselt ja pole ka selle muistendi elus võimalik tagantjärgi tuvastada. Need varem väljatoodud asjaolud (hämaravõitu põhjusega surmad, surnuvalvamine, uus töökeskkond, pime suur maja jms) võisid põhjustada teatavat rahutust ja stressi, mida osavamad ja tundlikumad lõpuks sõnastasid. Eespool esitatud tekstid on kõik juba väljakujunenud jutud. Looritsa ja Ariste poolt kirja pandud lood on pigem juba muistendi kokkuvõtted, aga siin võib olla tegemist ka kirjaliku teksti puudujäägiga suulise ees, st kirjalikult jäädvustatigi ainult lühikokkuvõte pikemast jutust. Ainus, mida nende kahe kirjaliku teksti abil praegu võib väita, on juba eespool väljaöeldud tõdemus, et niisuguste lugude rääkimise traditsioon oli 1920.-30. aastatel elav, igati asja- ja ajakohane. 1936. aastal ilmunud "Vaba Maa» artiklis on tegemist lõpetatud ja valmis muistendiga: kummitust ennast on siin nii hästi kirjeldatud, et ta sai siit alates kuju ja edaspidises suulises kasutuses ka nime - Lilla Daam. Sellest nimetusest sai omamoodi tunnussõna, mida muistendile viitamiseks kasutatakse.

\section{Tegelikkus ja edasiarendused}

Sellest ajast, kui puudus otsene vajadus juttu ühes kindlas seltskonnas üha uuesti ja uuesti esitada, hakati jutu süzheed täiendama majas vahepeal juhtunud sündmustega: iga majas juhtunud õnnetus lisas muistendile uue arenduse, värskendades teatud ajaks ka põhilugu ja kutsudes esile vajaduse sellest rääkida. Majas asetleidnud surmajuhtumid olid faktid, mida kõiki võiks iseloomustada sõnaga - õnnetusjuhtum. Nendest räägitaksegi nagu õnnetusjuhtumitest, aga samas seostatakse neid ka kummitava daami looga. Enamiku küsitletute teadvuses oli aga fakt ja fiktsioon praeguseks segunenud. Aja möödudes muutusid tegelikkuse piirid häguseks, ei teatud enam täpselt, mis juhtus ja kellega juhtus, ning iga õnnetusjuhtum sai 
omamoodi müstilise aura. Jutuloogika seadusi teades ja arvestades arutleti selle üle, et ohvreid pidi olema kolm, aga peaaegu ükski informant ei osanud kolme ohvrit oma jutusse põimida. Kõige üldisemalt teati kahte: asjaajaja (Eisenschmidt) ja üks ehitaja, kes end surnuks kukkus. Samas oli informantide hulgas inimesi, nende varem asetleidnud sündmuste kaasaegseid, kes esitasid onnetusjuhtumitest reaalseid jutuversioone.

Järgneva loo jutustaja on töötanud majas 50 aastat.

Vat selle majaga on nüid ju palju neid laipu ju. On ju? Teate neid ju järjest? See Eisenschmidt või. Kuidas ta nimi oli? Oli Eisenschmidt? Kuidas see ennast siis kirjutuslaua taga oli maha lasknud. Ei saadud siis sisse, hommikul toodi redel ja vaadati aknast. Siis oli selle uue, selle maja [mõeldud on 1963. aastal valminud maja] ehitusega oli ju kaks. Üks vana papi, kellel kuskil ei olnud elada. Elas siin ehituse noh nisukeses ajutises kuuris. Ja kurtis, et temal ei ole kuskil, et ta on nii üksik ja. Ja pääle maipühi papit ei olnud ehitusel. Ja siis ma ei tea, kas kuidagi juhuslikult, kas mingi tööriist kukkus keldrisse, leiti ta keldrist. Siis ta oli ennast üles poonud. Ja teine oli, see maja oli niikaugel, et siin olid kõik tellingud niimoodi ja siis selle klaasiga käidi küllaltki hooletult ümber. Siin oli all kõik niisugune klaasikildude rägastik. Ja siis olid need, ma ei tea, kas see oli venelane või. Üks pere tuli siia teisele korrusele, ma ei tea, kas siin käsikirjade ruumis vast umbes. Ja nad tegid mingid niisugused ajutised ahjukesed ja elasid siin. See mees oli muidugi joodik ja oli purjus ja naine läks lapsega poodi. Keeras ukse kinni ja läks. Aga see mees oli hakanud läbi akna välja tulema, no purjus ja tellingute pääl ja kukkus siia nendesse klaasidesse. Need olid tõesti nigu liustik, otsad püsti ja igatepidi. Ja ta vist siis sai kohe surma.

EK: Kas sellest ka räägiti, et Lilla Daam nõuab ohvreid?

Ei, ei räägitud. See on juba nüüd hiljem. Need olid kõik ikka õnnetusjuhtumid. Ja Eisenschmidtil ka lihtne lugu. Tal oli puudujääk. Siis olid need, Eesti Rahva Muuseumi loteriid olid ja temal oli sääl puudujääk ja sis vist pidi tulema mingi kontroll. Nii et ta, noh oli ummikus, ühesõnaga. Ei, need ei ole mingil juhul seotud selle Lilla Daamiga. Ja see Lilla Daami lugu on ikka puht vana Lintsi fantaasia. (Intervjuu nr 10)

Nii et reaalse versiooni järgi oli ehitusel kaks traagilist juhtumit, millest hiljem teati enamuses ainult dramaatilisemat - ehitajat, kes ennast surnuks kukkus. Sellest tuletati järgmine arendus: majas ei tohi midagi ümber ehitada ega korraldada, sest see ei meeldi Lillale Daamile või ehituste juures juhtub alati midagi traagilist (meestega).

Kolmandaks võimalikuks ohvritega õnnetusjuhtumiks peeti tavaliselt 1960. aastatel ehitatud maja avamisel saali laest allakukkunud krohvitükke. Seekord läks kõik õnnelikult ja imekombel keegi viga ei saanud, aga seda intsidenti mainiti alati, kui tuli juttu ohvritest.

No neid oli niivõrd palju ja siis räägiti...vat need olid minu arvates kõik natuke niuksed, natuke nöökimisi, kes neid enam tõsiselt võttis, aga see oli ikka tõesti õnnetu maja. Ohvreid oli seal ikka kohe mitu: üks sai õnnetult surma ja üks poos ennast üles ja nii onnneks oli see kolmas siis, et lagi kukkus pähe, aga keegi surma ei saanud. Need olid ikka tõesti tõelised need niisugused hukkasaamised seal majas. (Intervjuu nr 27)

Viimase (1990. aastate alguse) juurdeehituse juures enam midagi ei juhtunud. Sel ajal uppus segastel asjaoludel hoopis üks muuseumi töötajast naisterahvas (majast väljaspool). Seegi fakt omandas kollektiivis jutustades allmotiivi $\underline{\mathbf{9}}$ staatuse, kusjuures see liideti süzheele paindlikult, minnes kõrvale varasemast joonest: Lilla Daam nõuab meesohvreid. Oletatavasti muutus pärast Lintsi majast lahkumist jutu orientatsioon üldse, sest sellest ajast muutus ka 
varasem klausel - ilmutab end (ainult) meestele. 1970.-1990. aastatel on kummitust isikuelamusena kirjeldanud enamuses naised (vt edaspidi «Uskumise ja kogemuse varjatud tagamaad ja nende vahendamine»).

Lühikokkuvõtte jutust olid võimelised esitama kõik intervjueeritud. Noorem põlvkond (1970.1980. aastatel majja tulnud) ei tea (ja ei lisa jutule) Lintsi osa, tema kummitusenägemise lugu. Aastate jooksul lisatud detailide ja motiivide edastamisel jutus oli varieeruvus kõige suurem ja ühtlasi andis enamik jutustajaid erilise tähenduse just hiljem lisatud arendustele (ohvritele), tavaliselt sellele, mis juhtus nende kaasajal. Jutu tuum oli oma aktuaalsuse minetanud või oli tegemist hoopis sellega, et nii kompenseeriti tühimikku, mis oli tekkinud muistendi põhiliini teadmises, ja jutustajad kaasajastasid-aktualiseerisid juttu niimoodi enda jaoks. Majas asetleidnud surmajuhtumid kumuleerusid nii mälus kui edastatud juttudes tavaliselt üheks segaseks puntraks ja enamasti sain üsna segase ja ebaselge vastuse, kui palusin meie maja kummitusest rääkida.

Ega ma praegu ei teagi midagi. Olen niisama kuulnud töötajate omavahelisest vestlusest. Minul on nagu see meeles, et iga kord, kui mingi ehitus siin on, et siis võtab see Lilla Daam mingisuguse ohvri eks ole. Igasugu juurdeehituste juures juhtub õnnetusi. Ja see neiu ise, mingisugune õnnetu armastus ja enesetapu sooritanud vist.

Ja ma ei tea, siis igasugused folkloristid on teda keldris näinud siis või?[Naerab] Aga mina ise ei ole näinud. Ta ilmutab end rohkem meestele, naised teda üldiselt ei näe. Siis on seal all mingisugune laik. Verelaik või ma ei tea, millest on räägitud.

Ja noh see ei ole otseselt temaga, see juurdeehituse juures, see lae allakukkumine, eks ole, mingisuguse avamise puhul, mis oli ja. Siis vist selle uue juurdeehituse ajal olid ka jälle mingid enesetapud ja? Ehitajate mingid ónnetused, oli või? (Intervjuu nr 1)

Asjaajaja Eisenschmidti mahalaskmisloo ajel põhiloole lisatud arendust täiendati lõbu ja lustiga just folkloristide poolt (mahapestamatu vereplekk põrandal). (Nende tööruumid olid kunagise sündmuse tegevuspaigaks.) Eisenschmidti liin on heaks näiteks selle kohta, kuidas reaalelus kunagi toimunud sündmus omandab aja möödudes ja faktide tuhmudes aina muistendipärasema aura.

Aga mis Lillast Daamist edasi sai, tema nõudis ikka ohvreid küll. See esimene oligi võibolla kõige salapärasem lugu, see et jälle mingi sekretär või asjaajaja või raamatupidaja oli rahahädas, rahalistes raskustes ja tal on olnud võlgu ja talle on see olnud probleemiks. Nii et mitte romantilistel põhjustel ei ole ta teise ilma läinud, aga igatahes ühel hommikul leitud ta siis sellest ruumist, helikabineti põrandalt oma tooli või töölaua juurest ja selles kohas, kus on olnud tema süda, on siis põranda peal selline laik, mida pü̈̈ti sealt ära pühkida ja saadi ka. Ja kui mina seda nägin, siis oli ta niipalju ära kratsitud, et selle parketikihi sees oli nagu madalamaks võetud niisugune järk kohe, aga selle viirud olid südamekujulised küll, aga mitte niisugused, südamekujulised, nagu tehakse ärtu-taoline armunu süda, vaid niisugune, nagu on just see anatoomiline süda, ja palju suurem ka. (Intervjuu nr 28)

Lugu võidigi nooremate töötajate poolt esitada omaette jutuna, oskamata seda seostada kummitusloo põhiliiniga.

Mina ise kuulsin muuseumisse tööle asudes ja vanas helikabinetis kohvi joomas käies kõigepealt selle mahalaskmise loo ning mulle näidati (taastuvat) vereplekki parketil. Ma isegi ei mäleta, kas seda lugu seostati Lilla Daami ohvrinõudega. Küllap seda tehti, aga see oli minu jaoks kuidagi kauge ja arusaamatu. Tagantjärgi mõeldes oli see enesetapulugugi küllalt muinasjutuline ja meil oli kolleegidega paar tulist vaidlust selle üle, kas plekk parketil on ikka tõesti vereplekk või midagi muud. Igatahes, kuna tol ajal 
algasid arhiivi tutvustavad ekskursioonid, sealt siis rääkisime ainesesse sisseelamiseks naljatamisi ikka tolle loo ja näitasime plekki põrandal, sest mingi kraabitud koht või plekk seal ju oli. (Intervjuu nr 23)

Oli paradoksaalne, et nooremad jutustajad küll rääkisid vereplekist, kuid ei uskunud, et see on päris (pidasid seda pigem jutu tõepära jaoks tekitatud oluliseks detailiks), vanemad kolleegid olid enamasti veendunud, et see ongi olnud vereplekk.

Nii on juttu ärgitavateks teguriteks ühelt poolt konkreetsus (kindel tegevuspaik: helikabinet, kaminatuba; tuntud detailid: vereplekk, kaminakonks) teiselt poolt ebamäärasus, sest kõik on siiski ebaselge.

Muistendi säilimine (kestmine) sõltub eelkõige tema võimest muutuda, sealjuures on muutumise paradigmasid nii ajas kui ruumis alati mitu. Esiteks muudab ta eluea jooksul oma vorme (kuni metonüümi ja lühikokkuvõtte-tuumani välja), sõltuvalt esitamisel antud tähendusest saab ta olla personaalne kogemus, memoraat, muistend, kuulujutt, pajatus, lihtsalt konversatsiooniteema, nali jne (vt Bennett 1984: 45-63; Smith 1989: 94-95). Üheks jutu sisemise muutumise paradigmaks on uute motiivide või arenduste lisamine, mis lõppkokkuvõttes aktualiseerib muistendi üha uuesti ja uuesti. Nii tegid seda majas toimunud õnnetusjuhtumid.

\section{Jutustamine ja jutustajad}

Muistendi jutustajaid, selles mõttes, nagu muinasjutu jutustajad, rahvalaulude lauljad, rahvatantsude tantsijad või rahvamuusika esitajad, pole olemas. Muistendit ei peeta isikliku inspiratsiooni loodud kunstiks, mida esitatakse tähelepaneliku kuulajaskonna lõbustamiseks, pigemini on ta spetsiifiline teadmiste ala, millest jutustaja pakub informatsiooni. See ei ole mitte fabuleering, mis loeb, tähtis on hoopis teade, mida selle kaudu edasi antakse, ja teade vormib jutu viisil, mis tekitab mõtte ja tõmbab tähelepanu (Dégh 1992: 104). Jutustamine on protsess, kus nii jutustaja kui kuulaja(d) üksteist paratamatult mõjutavad, püüdes vastastikku teatud nõudmistele ning ootustele vastu tulla. Muistendi jutustaja räägib tõtt, st annab edasi tõest sündmust. Ta esitab võimalikult palju fakte ja tema jutustus on alati sõltuvuses auditooriumi liikmete toetusest, kes on valmis assisteerima jutustajat, lisades oma informatsiooni. (Dégh 1992: 106).

Kuivõrd konkreetne jutustaja võib mõjutada jutu tekkimist ja repertuaaris püsimist ühe kogukonna muistendi puhul? Tundub, et vägagi võib, sellega on ilmselt nagu peresiseselt edasikanduva traditsiooniga, kus kaasa mängivad ka peresisesed suhted. Jutt, et muuseumis kummitab, hakkas levima ikkagi tänu Ernst Lintsi isikule ja heale vahendamisoskusele. Algul oligi jutu rõhuasetus niisugune: esikohal oli see, et Lintsi nägi kummitust, ja teisel kohal kummituse enda lugu (parunipreili õnnetu armastus ja enesetapp ning kummitamas käimine). Praeguseks on enamiku maja töötajate teadvusse järele jäänud jutu tagumine osa (e jutu tuum). Kui Lintsi osalust selles süzhees ajalehe või paari parema jutustaja kaudu teataksegi, siis ei peeta seda enam oluliseks. Vaieldamatult oli see aga oluline. Üritan järgnevalt nelja Lintsiga kokku puutunud inimese meenutuste abil tuua välja neid väliseid ja sisemisi asjaolusid, mis teda kui inimest ja jutuvestjat kollektiivis karakteriseerisid, kuidas tema isik kujundas suhtumist ja juttu ennast. 


\section{Pärimus Ernst Lintsist}

1. Ernst Lintsi oli eriline isiksus.

Mall Hiiemäe kirjutab pajatuste puhul jutu seosest loojaga... «et ilmekaks jutustamiseks vajatakse ikka midagi konkreetset: sündmusest osasaamist, tegelase kõne kuulmist jms. See omakorda annab elamuse, mida jutustaja annab edasi aegade taha.» (Hiiemäe 1978: 47). Palju aastaid oli üheks edasirääkimise impulsiks Ernst Lintsi isiklik võlu ja tema jutuvestmisoskus.

Nii et Lintsi oli tuntud ja teatud inimene ja samal ajal niisugune küllaltki korrektne raamatupidaja ja isiksus. (Intervjuu nr 28)

2. Ernst Lintsi oli hea traditsioonitundja ja jutuvestja, kellele anti andeks ka see, et ta fantaseeris. Kõik taandus põhimõttele: peaasi et lugu on hea.

Mina ei ole ebausklik ka, sellepärast mina arvan, et vana Lintsi tegi selle. Tema tegi sellist nalja. ...Ta ei olnud mingisugune napsumees, ta oli jahimees ja kalamees. Tema vahel viskas mõne väikese anespitsi niiöelda. Nisukene oli fainshmekker $\stackrel{10}{ }$, nagu sakslased ütlevad. Tema tegi palju veini, võibolla oli, võttis paar pitsikest veini ja õhtul hilja siin üksinda töötas, jäi tukastama. Ja vat vahel näed ju nisukest und, et tõesti vaatad, et kus see asi nüüd jäi [nagu ilmsi]. Mina küll olen näinud nii. Temaga võis ka nii olla. Neid mõisalugusid kindlasti ta teadis, mismoodi see kõik oli, need ruumid ja. Ja kujutas ette või nägi, vahel näeb ju väga imelikke unenägusid. Ja võibolla seletas siis kellelegi. Ja tema oli niisugune, et tema võis vabalt ütelda, et vaata, ma nägin täna Lillat Daami. Ega tema ei hakandki ütlema, et ta seda unes nägi, sest tema oli niuke tore naljamees. (Intervjuu nr 10)

3. Järjepidevus kollektiivis. Muuseumi töötajaskond vahetus suhteliselt harva, suur osa inimesi töötas majas aastakümneid. Lintsi töötas peaaegu 50 aastat muuseumis. Isegi kui ta ise ei jutustanud oma kummituslugu, piisas teadmisest, et see on see mees, kes nägi Lillat Daami ja oskab sellest jutustada.

Ja siis jutt läks laiali ja need ajakirjanikud tulid ja kirjutasid kõik selle üles ja trükkisid Postimehes ära, et vaat, näe, seal majas puutus härra Lintsi, asjaajaja, härra Lintsi puutus kokku Lilla Daamiga. No vat ja niiviisi siis läks see jutt lahti ja mina seda ei ole kellegi käest kuulnud, et keegi teine oleks ka temaga kokku puutunud, vaid kogu aeg Lintsi oli majas, tema oli see esimene teadja ja see oli ikka Lintsi.

No jaa, nü̈̈d on üldse kõik kummitused moes. [Jutustaja tahab sellega öelda, et nende ajal see nii ei olnud.] Meie ajal eks ole Olli Jõgever oli, Lintsi oli, need, kes on algusest saadik seal majas olnud kohe. (Intervjuu nr 27)

4. Selle loo teadmine ja esitamine andsid talle kollektiivis erilise staatuse, mida ta ise ilmselt nautis.

Aga kui ma majja tulin 57, siis maja tutvustamise ajal loomulikult räägiti mulle. See oli vist Selma Lätt, kes seda rääkis, et vaat, näed, meil siin niuke kummitus, aga kõige paremini teab seda Lintsi, sest Lintsi ise puutus temaga kokku. No 
vat ja loomulikult Lintsi vaatas ka ikka, et kõik noored tüdrukud, ja tema hea meelega oli tähtis ja. (Intervjuu nr 27)

5. Lugu sobis tema isikuga, nende tähenduslike rõhkudega, mis tema enda puhulgi olulised olid. Ta ise andis jutustades sellele soolise tähenduse, rõhutades oma (härras)mehelikkust ja nõrkust õrnema soo vastu. Lintsi ise räägib 95-aastasena:

Mina mõtlen, et võibolla, et ma sel ajal olin ... olin nii ka segamini juba. Kell oli üheteistkümne ajal ôhtul, kui mina istusin seal selles ruumis, tegin tööd. Ja äkki, justnagu tuleks tuulevoog sealt kamina poolt ja mina vaatan ümber, et ilus väike daam. Ja kõige huvitavam see, et misukene see kleit seljas oli. Siin oli ristikheinalehed ja siin oli lilla [keep ?] see pääl. Ja mina mõtlen, et pagana pihta, et aga see oli hilja, et tagasi tuli see Int mind välja laskma, ust kinni panema. Ja nüid ole lahke, ja tema [mõeldud see] daam oli niisugune ... mm töntsakas. Vaatan, et äkki tohoo, et mis see nüid on, ja käed laiali, oot-oot, et küll ma teen talle nüid hullu, käed laiali, ja kadus ära, ja see on õige, mina rohkem teda näinud ei ole. (Ja tema on vist..., aga see Treial, see nägi... ma ei tea, mis siis see õieti nägi. Nad nägid kõik, aga mind ei huvitand see. Mina ei usu...) (Vt lisa 2)

Vanemad kolleegid andsid ise seda teadvustamata jutule samad rõhud, kui Lintsi ise: kena noor vallaline mees kohtub ilusa daamiga ja käitub üsna enesekindlalt.

Mul on meeles, et ta rääkis, et ta istunud selles kaminasaalis sel ajal kui Eesti Rahva Muuseum korraldas neid loteriisid maja ostmiseks, ja ta tegi neid kokkuvõtteid ja üks ôhtu ta jäi ilmselt kauemaks siia, ja siis kas ta jäi tukkuma või mis siis juhtus, seda ei tea, aga tema nägi, et kusagilt siit kappide vahelt tuleb üks daam tema poole, tema kui noor härrasmees ja sirge ja kena mees muidugi. Ega ta seda ise ei rõhutanud muidugi. (Intervjuu nr 2)

...direktori kabineti eesruumist tema läks ja nägi, et seal on üks naine, lilla kleit seljas, ja temal ei tulnud mitte mingisugust niisugust tunnet, et see oleks midagi üleloomulikku, vaid tema kohe arvas, kelle õde see pidi olema - minu jaoks olid need inimesed võorad - et see on nü̈̈d selle naise õde, ja tema, noor vaba mees, läks ja tahtis seda kallistada selja tagant, võtta ümbert kinni. Ja tema haihtus tema käte vahelt ära. (Intervjuu nr 27)

EK: Aga miks seda juttu räägitakse?

No mina arvan, et asja põnevaks teha.

Mis asja?

Elu. Lintsi oli vallaline, siis tal olid naised. Neid ta tahtis muidugi hirmutada, et siis ta saaks kaasa minna. Ennast tähtsaks teha. Ta oli muidugi niisugune muhe ja humoorikas mees. (Intervjuu nr 2)

Nii et pärimuse järgi oli Ernst Lintsi hea jutuvestja ja nagu eespool öeldud, ilmselt ka hea traditsiooni tundja. Temale kuulus kollektiivis auväärne positsioon. Raamatupidaja on asutuses kõigile töötajatele tuntud isik. Peale selle töötas ta majas ligemale viiskümmend aastat, praktiliselt asutuse loomise algusest. Paljud inimesed, kes temaga olid kokku puutunud, tarvitasid tema nime ees sundimatult-loomulikult sõna «härra» ja rõhutasid seda, et ta oli isiksus. Kuigi kitsamas ringis teati ju, et ta loo välja mõtles, ei takistanud see juttu edasi rääkimast. Need 
poolvarjatud tähenduslikud rõhud, mis Lintsi jutustamisel andis ja mida ka need kaks jutustajat, kes lugu otse temalt kuulsid, samuti edastasid, hakkasid taanduma, kui tema isik enam kollektiivis muljet ei avaldanud ja hilisemad põlvkonnad sellest enam midagi ei teadnud. Selle üle, kas muistend muutub, levides ühelt põlvkonnalt teisele, on avaldatud nii poolt kui vastu seisukohti (vt Mullen 1972: 102). Kogukonna muistendi puhul võib ilmselt öelda, et ühelt põlvkonnalt teisele kandudes muistend muutub, mitte ainult lisatud ja unustatud motiivide, vaid ka algsel esitusel antud tähendusvarjundi poolest. Üks Lintsiga tema vanas eas kokku puutunud kolleeg konstateerib:

Ja küllap ta noores eas oli kavaler ka, aga siis oli ta niisugune väga hõredate juustega või polnudki tal juukseid enam, niisugune papi. (Intervjuu nr 28)

Enam-vähem püsiva koosseisuga kollektiiv ei mõju innustavalt ühe ja sama jutu korduvale muutusteta reprodutseerimisele. Hea jutuvestmine ja ühe jutu püsimine elavas traditsioonis eeldab kuulajaskonna vaheldumist, mida püsiliikmetega kollektiivis pole. Küsitletutest enamik ütles, et ei oska rääkida ja ei ole kunagi rääkinudki kogu ilusat lõpetatud lugu paljude sinna juurde kuuluvate üksikasjadega. Küll aga on kollektiivis alati olnud üldiselt teada üks või mitu väga head jutustajat vanemast generatsioonist, kelle juturepertuaari kuulub ka muistend Lillast Daamist. Need on kogu kollektiivi poolt tuntud ja hinnatud jutustajad, kes mingil konkreetsel vajadusel (maja külastavatele ekskursioonidele, uutele töötajatele jne) muuseumi kummitusloo ette kannavad. Seda võib niisugusel juhul pidada peaaegu et muistendi professionaalseks ettekandeks, sest jutustaja teeb seda korduvalt kinnistades ja lihvides iga ettekandega oma lugu ja artistlikkust. Samas on teada, et jutustajate repertuaaris on kaks erinevale publikule orienteeritud muistendi versiooni. Ekskursioonidele esitatakse viimistletud 'esindusversioon' muistendist (romantiline armastuslugu), millele jutustaja lisab omalt poolt intrigeeriva lõpu, samaaegselt kinnitades ja ümber lükates oma juttu, jättes uskumise või mitteuskumise publiku asjaks (vt intervjuu $\mathrm{nr}$ 2). On teada ka, et kaks muistendi 'esijutustajat' on kasutanud mälu värsendamiseks oma kirjalikke ülestähendusi muistendi kohta, "Vaba Maa» artiklit ning Ariste kirjutatud arhiiviteksti. Pikem arendustega variant tuleb kollektiivis ettekandmisele haruharva, kas seoses uue töötaja tulekuga või osaliselt 'grupi saagana', kus ei jutustata terviklikku lugu, ei ole vastamisi üksikesinejat ja auditooriumi, vaid kõik võivad olla korraga esitajad ja kuulajad. Grupi saagas on fookuses nali, mängulisus, ootamatus, kommunikatsioon, dialoog ning nad kutsuvad esile kollektiivi ühist minevikku. Ühtlasi on niisugune jutuvorm kodeeritud teade, räägitakse ühiselt kõigile arusaadaval tee-

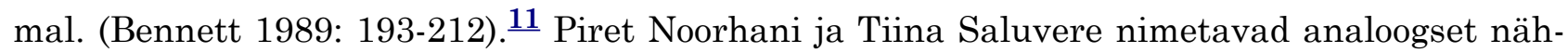
tust kollektiivis mänguks selle sõna laiemas tähenduses. St mäng, mille reegleid ja tagamaid kõik kollektiivis teavad ning milles lõppkokkuvõttes avaldub ühe inimgrupi loovus. (Noorhani \& Saluvere 1996: 26-38). Nii kerkib Lilla Daami teema esile omavahelistes kohvilauavestlustes, ootamatutes analoogolukordades jm.

Mina pole ise kellelegi kunagi jutustanud ja üksikasju ei oska ka seletada. Minul on rohkem meeles niisugused situatsioonid, kus me istusime seal helikabinetis ja vahel tuuletõmbusega läks uks järsku lahti ja keegi ütles: Lilla Daam. Ja siis naerdakse. Aga kõik ju teavad, et selle taga on üks müstiline lugu. Või siis öeldi, kui keegi oli lillas või öövalve ajal midagi kolistas. (Intervjuu nr 33)

Ellen rääkis ju. Ellen on hea jutustaja, tema rääkis ju. Mina ei ole hea jutustaja, mulle ei jää ka meelde. Kui mina tulin eile fondist kontsaklõbinal, siis Räim küsis, et oi mina mõtlesin, et Lilla Daam tuleb. Ja mina küsisin, et oi, et kas see on siin uue maja poole peal ka nähtud. Ja Räim ütles, et ei. Ütles ei, aga võibolla oli see niisuguse lõ̃pimise eest. (Intervjuu nr 23) 
Heino Räim ja Ellen Liiv on olnud aastaid kollektiivis kaks põhilist esijutustajat, kelle sõnastatu peegeldus hägusamalt tagasi teiste jutustajate esituses. Rahvaluule arhiivis oli see aastaid seltskonda liitmise lugu - initsiatsioonijutt -, mida kauaaegne osakonnajuhataja Ellen Liiv kollektiivi tulnutele rääkis. Jutustamise motivatsiooni järgi rääkijaid iseloomustades võib konstateerida, et on uskujaid, edevusest rääkijaid, naljatlejaid, kemplejaid kui ka tarbe pärast rääkijaid. Ühel juhul oli hästi serveeritud kummituse nägemise lugu andnud ilmselt põhjust tülikatest öövalvetest pääseda.

\section{Uskumise ja kogemuse varjatud tagamaad ja nende vahendamine}

«Skeptikust uurija Frank Smythe rääkis, kuidas ta oli vaimu välja mõelnud. Ta tegi seda kindla kavatsusega. Idee kohaselt tuli tal mingi olematu kummituse legend koostada, seda levitada ja vaadata, mis edasi juhtub. Selguski, et mitu tunnistajat hakkas Londoni sadama piirkonnas ringiuitavast fantoomist rääkima. Just sinna oligi Smythe oma võltsviirastuse paigutanud. Kui ta üles tunnistas, et tegemist on tema lihtlabase väljamõeldisega, keelduti teda uskumast...." (Randles \& Hough 1998: 162)

Linda Dégh ja Andrew Vázsonyi jagavad muistendi võtmeküsimuse - usun või mitte - järgi jutu vastuvõtjad ja levitajad viide kategooriasse: uskujad, mitteuskujad, skeptikud, oponendid ja ambivalentsed. Tõsiasi on see, et iga nende kategooriate liige võib omal moel osa võtta muistendi formeerumis- ja transmissiooniprotsessist (Dégh \&Vázsonyi 1971: 300 - 301). Suhtumine kummitusjuttu laseb pilku heita kaasaja inimese mentaalse maailma varjatud eesriide taha. Miks siis ikka püsib selline jutt, mida keegi tõsiselt ei võta ja kas ikka üldse ei võta? Mis aitab sellel püsida? Ma ei küsinud otseselt kelleltki, kas ta usub kummituse olemasolusse. Tavaliselt toimusid minu ja kolleegide vestlused kergelt lõbusas ja nöökivas toonis, ometi koorus selle kergeilmelise pealispinna alt välja päris ilmekas usundiline foon, mis muidugi isikuti väga erines.

Enne kolleegide intervjueerimist olin nagu ähmaselt kuulnud, et majas on keegi mees kunagi varem (enne minu tööletuleku aega) näinud Lillat Daami. Mäletan, et sellest rääkisid vanemad kolleegid kunagi naljatamisi kohvilauas. Nüüd maja töötajaid intervjueerides leidsin üllatusega, et viimaste aastakümnete jooksul teati vähemalt viit inimest, kellel oli olnud kummitusega isiklik (visuaalne) kokkupuude, neist viimased kolm viimasel kümnendil. (Kahte neist õnnestus mul küsitleda.) Üks küsitletu väitis, et ta küll ei näinud, kuid tajus selgelt kummituse kohalolekut, neljal töötajal oli seletamatu kuulmiselamus, kümmekond inimest tunnistas, et on majas hirmu tundnud. Isikukogemuste puhul on üsna hästi seletatav, miks ma ei olnud sellest midagi kuulnud: igat konkreetset juttu teadis

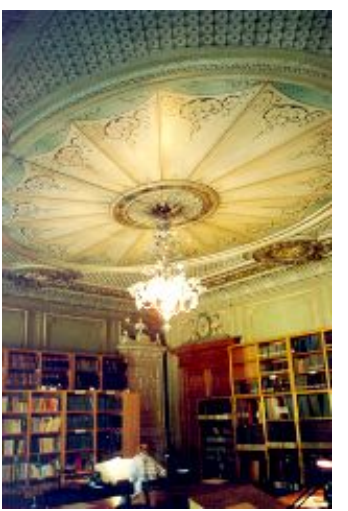
ainult kitsas ring maja töötajaskonna hulgast. Kuigi mulle vahendati seda lugu tagantjärgi kui lõbusat seiklust, võis siiski aru saada nendest vastuolulistest tunnetest, mis inimesi valdas millegi seletamatuga kokku puutudes ja veel rohkem sellest jutustades. Sama tõdemuseni jõuab ka Leea Virtanen oma lühiuurimuses kummitusjuttude rääkimise kohta. Ta ütleb, et tarvitseb vaid kolmandal välja ilmuda, sellal kui kaks töötajat majas toimuvatest imelikest asjadest räägivad, ja nende jutt muutub kohe naljameelseks ja lõõpivaks. Rohkem kui kummitust ennast peljatakse seda, et sellest jutustajaid peetakse psüühiliselt tasakaalututeks inimesteks. (Virtanen 1991: 414-415). See ühiskonna sisemine arusaam on seotud materialistliku maailmavaate võidukäiguga (arusaam, et tsivilisatsioon tähendab liikumist üleloomulikust maailmast materialistlikku, ebausk contra ratsionaalsus). Sedasama raskust kahe vastandliku maailmavaate sobitamisel on rõhutanud Gillian Bennett vaimulugude rääkimise traditsiooni uurides. (Bennett 1999). Linda Dégh arvab, et paljud kogetud elamused jäävadki 
väga isiklikeks või peresiseselt ringlevateks kas sobivate kaasatundvate kuulajate puudumise tõttu või hirmu pärast tekitada piinlikkust iseendale või oma perele. $\underline{12}$ Talupojaühiskonnas kuulusid lood vaimudest, kummitustest ja kodukäijatest sealsesse reaalsesse maailma, need ei olnud ainult pimedate õhtute meelelahutus. Vaieldamatu fenomen, mis mõjutab tänapäeva inimese maailmavaadet on seegi, et kuigi mõningatel meist võivad olla seletamatud või üleloomulikud kogemused, puudub tänapäeval nendest rääkimise traditsioon, nagu on kadunud ka enamik vanadest usundilistest muistenditest. (Virtanen 1992: 225-231).

Läksin siis sinna, oli varane hommik ja kõik vaikne ja ronisin üles redeli peale, et kuhugi ülespoole panna raamatuid. Need riiulivahed läbi ei paista muidugi. Ja äkki kuulen, tükk aega olin olnud ja kuulen äkki, et kust trepp lõpeb, eest koridorist hakkavad sammud tulema. Kõps, kõps, kõps, läbi esimese ruumi ja siis teise, kus mina olin, ja tulid eelmisse vahesse, jäid täpselt minu kohal seisma, kõpskingad, kusjuures ma mõtlesin, et kellele need võiks kuuluda, keegi ei kõpsutanud. .... Ja siis mina olen redeli peal ja mõtlen, et huvitav, hingamistki ei ole kuulda, hakkas kuidagi imelik tunne. Küsisin, kes seal on, keegi midagi ei vastanud, täielik vaikus. Tulin alla, vaatasin eelmisse vahesse, mitte kedagi ei ole. [Naerab.] Selle peale hakkas kohe kuidagi hirm, nii et ma jooksin sealt minema, isegi tule jätsin põlema. Ilmselt jah. Mingi väega ei ajand mind sinna tagasi. Ma ei mäleta, kas ma kutsusin Irene ka, et lähme kustutame tuled.

EK: Miks sa arvad, et see Lilla Daam oli? Kas sa teistele ka rääkisid siis?

Ei, ma ei rä̈̈kinud. Jah, nagu midagi hoiaks tagasi, et võibolla mõeldakse, et... ma ei oska öelda, mis hoiab tagasi. Nü̈̈d ma olen küll kõigile rääkinud. Aga jah, kuna ma teadsin, et Lilla Daam siin on, et kes seal muu võiks olla. Kummaline, et üldse kuuleb nii selgelt. (Intervjuu nr 18)

Selgus, et aset leidnud õnnetuse faktil põhinev ja muistendile liidetud arendus võis aktualiseerida ka isikuelamuse (hirmuelamuse). Järgnevalt katke kahe kolleegi omavahelisest vestlusest, mis minu küsitluse ajal tekkis.

P: See oli üks selline nali. See oli ikka seoses sellega, et uut maja ikka muudkui ehitati ja ehitati. Ja siis oli ju see pärimus, et iga uus juurdeehituse valmimine nõuab ühe ohvri ja see ohver on mees. Aga siis see Lilla Daam läks moodsaks ja niiöelda sooliselt ei diskrimineerinud, vaid võttis naise. [Naerame.] Uusim maja läks ju naisega.

\section{T: Selle kringliga?}

P: Ja see oligi minu jaoks selline emotsionaalne teadvustamise hetk kringliga. Ta läks vist kringliga?

T: No tal oli ju, kringel leiti sealt. See kringel oli kaldal ja tema ise oli seal vees. Nii et öeldi, et pool meetrit vett, et täitsa seal kalda ääres. Ja ta lamas seal ja kringel oli kõrval.

See oli täitsa õudne. Mina meie keldreid muidu üldse ei peljanud, üldse ei pelga, aga vata siis oli mõnikord õudne.

T: Jaa, oli küll.

P: Ja eriti see kord, kui T. tuleb keldrist uurijate tuppa, kus me siis kõik istusime rivis nigu mukid, ja küsib, et mis sa siin teed. Ma ütlesin, istun siin. Aa, ma nägin sind just keldris! [Üks kõneleja naerab.] Läksid saba lehvides piki koridori tahapoole ja tema ei pannud välisustki kinni, arvas, et... ja tuligi üles, ust kinni ei pannud, et mina jäin keldrisse ju. Ja minul hakkas nii oudne, et mina ei julgend üksinda keldrisse minna. Mina ütlesin talle, et nü̈̈d lähme koos, tema ka minu arust ei julgend. (Intervjuu nr 8) 
Kaks kummituse nägijat, keda intervjueerisin, vahendasid lugu rohkem mitteuskumise traditsiooni päraselt (vt Bennett 1999: 9-38), st püüdsid mõistatuslikku juhtumit seletada ratsionaalsel moel: valguse langemise nurga, väsimuse, ettekujutuse jms abil. Neli viiest juhtumist olid stereotüüpsed kummitusenägemised nii aja, koha kui ka muude asjaolude poolest: vana tühi maja, üksiolek, poolärkvelolek, pimedus või hämarus jms; ja kolm neist leidsid aset just öise valvekorra ajal.

Õhtu oli juba käes, kell oli maru palju, mina muidugi täitsa üksinda maja peal. Kõhe ei olnudki, astusin siit uksest välja ja vaatan koridori lõppu ja seal ta oli. Aga ta oli valges kleidis. Ta oli nagu arhiivi minnes selle trepi otsas, aga ta oli valges kleidis ja pikk ja sale ja graatsiline kuju, noh, graatsilise mõtlen vist ise juurde ja saleda. Aga igal juhul seal ta seisis ja läks trepist ära alla, mille peale mina muidugi kiiremini kui muidu tõmbasin ukse kinni ja lippasin alla valvuri juurde ja kirjutasin ennast välja.

EK: Kuidas sa aru said, et see kummitus on?

Ta ei olnud nagu üldse materiaalne, ta oli niisugune, nagu meie ettekujutuses kummitused on.

Aga ma polnud üldse kuulnudki, et mis kõik siin majas on mingi õnnetu armastus, lihtsalt kuidagi kõik see vana maja pool ja. Seda ma kuulsin pärast. (Intervjuu nr 12)

Kõige erandlikum nägemus oli aset leidnud päevaajal endises helikabinetis (Eisenschmidti hukkumise kohas) ja mitme tunnistaja juuresolekul, kes said jälgida kogeja reaktsiooni ja kes nüüd aastate pärast kogeja hirmuelamust ning segadusesolekut palju värvikamalt vahendasid, kui seda nägija ise mulle söandas teha. Kui kogukonna usundiline muistend, mis olemuslikult on ju mõeldud uskumiseks, on aastate jooksul kaotanud oma aktuaalsuse värvi ja sära ning seeläbi ka palju usutavusest, siis niisugused isikuelamusena jutustatud lood kinnitavad ja renoveerivad ka muistendi mainet, tekitades justkui uuesti muistendile vajaliku usundilise fooni.

Mis see siis on, mis see seda uskuma paneb, noh et see käib nagu niimoodi aastakümneid ikkagi kaasas selle majaga või inimestega ja keegi nagu ei ütle ka ikka päris otse ka et ahh... [viitab jamale]?

Ei noh, ongi, et mis siis ikkagi oli see, millest minu tuttav mööda astus. Mis teda ehmatas, et midagi seal pidi olema, et me sellest temaga üldse rääkima saime hakata, sest see oli nagu põhjuseks, miks see Lilla Daami teema üldse tuli, sest see tuleb alati siis, kui midagi on toimunud. Ja mis see täpselt siis toimus, seda on praegu juba päris võimatu öelda ja miks me sellest rääkisime ja miks olid minul need lillad riided seljas, no see on ju jumala juhus. (Intervjuu nr 15)

Maja kollektiiv koosneb peamiselt naistest, mehed on olnud olulises vähemuses. Ilmar Soomere statistilised andmed paranormaalsete nähtuste kogejate kohta näitavad, et naiste hulgas on tunduvalt rohkem üleloomulike nähtuste kogejaid. (Soomere 1972: 742). Sel juhul ei olegi üllatav, et nende viie isikuelamuse puhul on 4 kogejatest naised ja ainult üks mees. See asjaolu põhjustas ilmselt ka kogukonna muistendi sisu paindliku muutumise detailide suhtes. Algul oli ju nagu paika pandud, et see vaimolend nõuab ohvriteks mehi ja ilmutab end nimelt meestele, ent viimastel kümnenditel on rõhuasetus oluliselt muutunud: teda on näinud naised ja viimane õnnetu surmajuhtum majas on juhtunud samuti naisega.

Kunagi isikuelamusena kogetud ja edasi jutustatud kummituselugu võib aastakümnete möödudes omandada pajatuselise näo, mida jutustatakse vahetevahel meelelahutuseks. 
Tema noh ütles, et temast ikka siin majas, et teda ei tunnustata nii palju, kui teda vaja on tunnustada ja. Keegi ütles, et kõik priviligeeritud inimesed on vähemalt ühe öö siin majas maganud. Jah, ja noh Mälton siis kah oli tulnud siis ôhtul majja ja oli ütelnud Enele, et ma ei saa siin olla kodus ja, et kas ma võin siin sinu kabinetis sääl üleval olla. (Ene ütles, et noh ole siis jah.) Tal oli seal kushett ja. Ja siis oli... Enele tõi keegi ounnu ja ounad olid võrguga sääl kusheti ääre pääl, nurga pääl. Ja noh, Mälton oli heitnud siis sinna magama ja näeb siis, (ma ei tea, unes või kus ta nägi) ja näeb et see Lilla Daam tuleb ja istub seal Ene laua taga ja kutsub teda ka kohvi jooma. Joob kohvi.

Jah ja ütles, et oli kohe täielik Lilla Daam ja niuke uhke ja istub sääl, aga mitte Ene koha pääl, vaid vastas ja ja kutsus teda siis kohvi jooma ja siis tema oli sealt üles karanud ja pani minema ja siis ta istus...too oli kuskil kell kaks öösel ja noh niuke talve-või sügiseõhtu oli ja läks siis istus valveruumis hommikuni. "Mina sinna tuppa enam ei lähe!" Ja Ene tuleb hommikul tööle, vaatab, õunad kõik põrandal laiali, kõik see mingisugune, tekk oli vist seal, tekk põrandal. Mis asi see seal juhtunud on? Aga Mälton nägi Lillat Daami. [Naerab.] (Intervjuu nr 19)

Üks oluline asjaolu, mis aitas ja praegugi aitab hoida kummitusteemat kogu aeg värskena, on maja öövalve. $\underline{13}$ Tavaliselt räägiti sellest nöökamisi omavahel, aga tuli ette ka seda, et mõned inimesed kartsid ja keeldusid öövalvesse jäämast. Tavatu olukord, kus üksinda ollakse pimedas suures majas, on asjaosalisele olnud nii erakordne, et veel aastate pärast mäletatakse oma sel ajal nähtud unenägusid ja kuulmiselamusi.

Ja kui me siin valves olime, siis oli tõesti siin kaminasaalis kuulda, noh, sel ajal kui mina majja tulin, oli kaminasaal juba hoidla. Ja siis olid suured kõrged riiulid seal. Siis muidugi nagises seal, nii nagu keegi kõnniks. Mina ka olen seda naginat küll kuulnud. Sest nii vaikne öösel, ja sis ühtegi autot mööda ei sõida ja siis kostuvad nii hästi läbi ja see nagin tundus küll nagu astuks keegi või kõnniks. Hiljem on räägitud seda, et on nähtud, kuidas ukselingid käivad ja uksed lahti lähevad ja kedagi ei ole ja. Seda on räägitud nü̈̈d. Nüidne üks valvuritest on nagu öelnud, et uks siit kuskilt lahti läinud või link liikunud ja pärast pole kedagi olnud. (Intervjuu nr 2)

Intervjuude käigus tulid isikuelamuste teadmises välja tuntavad piirid, mis toimisid jutu levikul erinevate põlvkondade, erinevate väiksemate kollektiivide (arhiivide) või koguni lähedaste sõpruskondade vahel. Tavaline on, et ei mäletata kummitusenägemise lugu rohkem kui ainult ähmaselt ja tavaliselt seda, kes nägi. See on nagu lühikese informatsioonilise teatena, kus tähelepanu keskmes on juhtum (keegi $\mathrm{N}$ nägi kummitust) mällu fikseeritud ja levib majas kuulujutuna, mis kahtlemata tugevdab muistendi renomeed. (Vt ka Mullen 1972: 95-109).

Kui kummituselamust personaalkogemusena teab ainult mõni kogejale lähedane inimene kollektiivis, siis üldisemalt pakuvad kõneainet majas juhtunud ebatavalised asjad (uste sulgumine iseenesest, laelambi kummaline purunemine, telefonikõne inimtühjast raamatukogust, müra raamatukogus jms). Kuuldus nendest levib kõmuna majas ja elustab naljatamisi jälle kummituse teema.

\section{Kogukonna usundiline muistend kui homogeenne tervik}

Oma intervjuude lõpupoole sai mulle selgeks, et pole õige lahutada tervikut osadeks, samas ei saa jälle tervikut iseloomustada ilma üksikuid osi tundmata. Meie Lilla Daami jutt on kui puzzle, mis kunagi valmis ei saa. Linda Dégh peab muistendi peamisteks tunnusteks lõtva vormi ja sisu, mis kõiguvad stabiilse tuuma ümber, ning muistendile iseloomulikku sidet reaalse elu ja usundiga. (Dégh 1965: 78) Seda seisukohta Lilla Daami jutu puhul edasi arendades võiksime joonistada tingliku skeemi, kus mõjuvälja keskmes asub usundiline muistend, mille võimalik täienemine võib toimuda tegelikkuse mütologiseerumisest tingitud arenduste, 
motiivide või detailide liitmisega. Jutu tuumast lähtuvad isiklikud üleloomulikud kogemused kinnitavad usku ja renoveerivad seega muistendi mainet. Üldisemasse mõjualasse jääb kogukonna kollektiivne käitumine (e kogukonna rutiin), mis tugineb üleüldisele muistendi tundmisele. Selle väljunditeks on igasugused mängud, naljad, keelekasutus, konversatsiooniteemad jms, mis tulevad esile kogukonna igapäevases käitumises. (Vt joonis.)

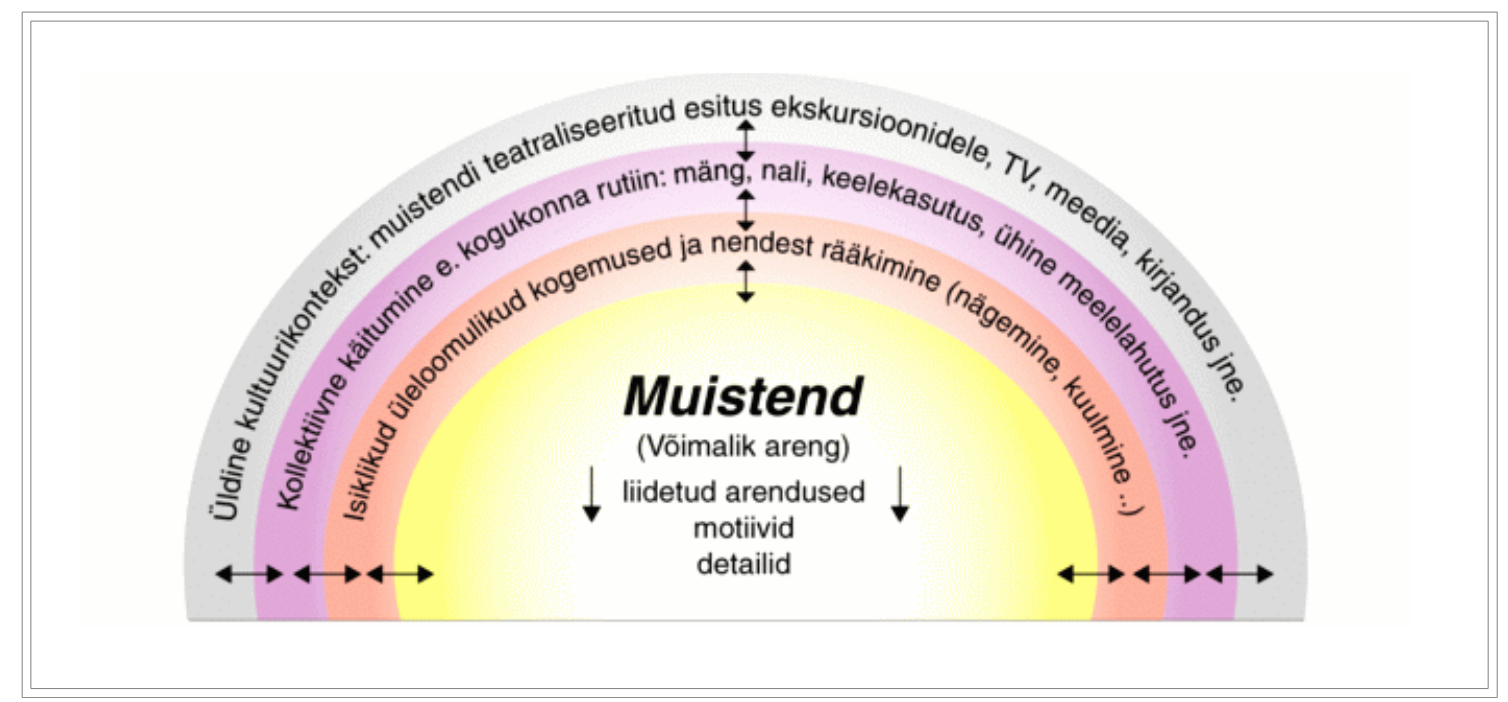

Kogukonna muistendi teadmine on omamoodi identiteediküsimus. Lilla Daam on tunnuslause, selle teadmise järgi saab määrata, kas inimene on muuseumis töötanud või ei. Sellel tasandil avaldub kõige selgemini ka kogukonna eripära, mis väljendub heas traditsioonitundmises ja intuitsioonis.

Küsitletutest valdasid folkloristid ja kirjandusloolased traditsiooni kõige paremini, rohkem tunnetuslikke kogemusi oli jälle ülejäänutel. Intervjuudest tuli välja, et majja tulnud uutel töötajatel oli algul raske harjuda niisuguse rutiinsena näiva tööga ja tundidepikkuse istumisega. Tegemist oli lõppematu tööga, mis kunagi valmis ei saanud, mille käegakatsutavat tulemust ei nähtud ja mida tuli teha üksi, ilma et sul oleks vaja olnud kellegagi suhelda. Ühine suhtlemine ja mänguline dialoog aitas olukorrast üle olla ja kohaneda. Niisuguse olukorra üheks väljundiks sai näiteks Lennarti-mäng. (Vt Noorhani \& Saluvere 1996: 26-38). Ise mäletan, et Eesti Rahvaluule Arhiivis oli umbes samal ajal samuti suurem põlvkondade vahetus. Umbes samast ajast on pärit ühised kaustikud, $\underline{14}$ kuhu kirjutati üles kõik kolleegide põnevamad laused, sententsid, mõtteavaldused, olulisemat ümbritsevat päevakajalist kroonikat. Kaustikusse kirjutajad olid eraldi väike kollektiiv suuremas kollektiivis, isikud, kes omavahel tihedamalt suhtlesid. Sellises seltskonnas omandati ja kasutati naljatamisi ka varasemat jutu- ja usundikogemust, filtreeriti läbi enda suuremas kollektiivis käibel olevaid suhtlusmalle. Neid kahte vihku sirvides leidsin mitu repliiki-viidet Lillale Daamile.

Näiteks. (Lilla Daami muistendi metafoorsest kasutamisest)

Tuled pahaaimamatult keset sessi tööle ja sind ümbritsetakse vanade lillade daamide, sibulaõunte, liivakookidega ja juttudega kurdide raskest saatusest. (Sissekanne tehtud kuskil aprillis 1994). 
(Kollektiivi fikseering muistendi kasutamisest meedias.)

20. I - arhiivinduse seminar (?). Astrid läks. Kõik on moodustanud suurde tuppa suure tropi. Räägitakse, räägitakse. Eile õhtul oli meie maja kummitus /Lilla Daam/ televisioonipurgis. (1992)

(Naljaka mängulise ja intrigeeriva vestlusteema ülestähendus, mis toimus ühises kohvilauas)

Kohvilaud otsustas: pidada, st tähistada Lilla Daami nimepäeva sel moel, et kõik daamid riietuvad lillasse.

Erna (tõsiselt, mõtlikult, süvenenult): Ma mõtlen, kas mul on midagi...üks mantel vist ...(sissekanne augustis 1993).

Muistendit on kasutatud kahel korral ka kollektiivi ühistel pidudel. Sellest näitemängutegemisest ja kummituse ebaõnnestunud hääle jäljendamisest liikusid asjaosaliste seas veel omad pajatused. Lõpptulemusena aktiviseeris niisugune ühine mäng ka muistendit ennast, sundis seda meelde tuletama. Muistend ise, selle tekkimine, jutule arenduste lisamine, selle kasutussituatsioonid, jutustamine ja jutustajad - kõik see sisaldab kogukonnas aset leidnud ja läbi elatud sündmusi, tuntud inimesi, ühiselt vallatavat jututeemat. See on kogukonna ühine ajalugu läbi (story) ühe jutu, mis loob kokkukuuluvustunde.

Kõik tänapäeva vaimulood kuuluvad kaasaegsesse kultuurikonteksti. 1990. aastatest on muistendit rohkem kasutama hakatud kui erilist kaubamärki muuseumi esindamiseks. Pea kõigile raamatukogu külastavatele ekskursantidele räägitakse kaminatoas romantiline lugu parunipreilist, kes kunagi samas toas õnnetu armastuse pärast end hukkas, näidatakse seda kaminakonksu, mille otsa ta end poos.

Lilla Daami loost on mitu korda kirjutatud ajalehes ja tehtud TV-saade. Meedias pakutakse kummituslugu enamasti kui meelelahutust, millel ei puudu ka uudise hõng. Juba 1936. aastal ilmunud artiklis oli rõhuasetus sellel, et ühes majas mitte ainult kummitab, vaid et kummitab just sellises kohas, kus niisuguseid ebaharilikke asju kogutakse. Selle loo puhul on harukordne see, et algusest peale on olnud olemas jutu ajakirjanduslik detailsem ja stiliseeritum variant, mida on kasutatud süzhee kontrollimiseks, mis on kinnitanud jutu tõepära ning on lõpuks mõjutanud ka suulisi variante. Meedia vahendusel on lugu jõudnud ka teatrilavale.

P: Nõukogude ajal seda pärimust ei hü̈̈tud meedia kaudu. Ei hüütud.

T: Jah, aga nü̈̈ on see etenduseski sees, seal "Kummitussonaadis" see oli. Noh [lavastaja] Toominga "Kummitussonaadis" oli, nad kasutasid Tartu Postimeest, kus oli see viimane lugu. Ja etendusse oli põimitud, et luges lehte, et Kirjandusmuuseumis kummitab Lilla Daam. Noh ja niimoodi, eks ole, seda levitatakse. (Intervjuu nr 8)

\section{Käsikirjad}

Eesti Rahvaluule Arhiivi käsikirjalised rahvaluulekogud:

E - Eiseni kogu

ERA - Eesti Rahvaluule Arhiivi kogu

EFA - Eesti Folkloori Arhiivi kogu

Soomere, Ilmar 1972: 1000 parajuhtumit Eestis. Viljandi. ERA käsikiri nr 71. 


\section{Kirjandus}

Aru, Krista 1997. Kirjandusmuuseumi maja ja selle elanikud. Tartu Postimees, 26.11.

Bennett, Gillian 1984. The Phantom Hitchhiker: Neither Modern, Urban or Legend?

Perspectives on Contemporary Legend: Proceedings of the Conference on Contemporary Legend. Sheffield, 45-63.

Bennett, Gillian 1989. Playful Chaos: Anatomy of a Storytelling Session. The Questing Beast.

Perspectives on Contemporary Legend. Volume IV. Edited by Gillian Bennett and Paul Smith. Sheffield, 193-212.

Bennett, Gillian 1999. Alas, Poor Ghost! Traditions of Belief in Story and Discourse. Utah. Brunvand, Jan Harold 1981. The Vanishing Hitchhiker. American Urban Legends and Their Meanings. New York \& London.

Dégh, Linda 1965. Processes of Legend Formation. IV International Congress for Folk-

Narrative Research in Athens (1.9.-6.9.1964). Lectures and Reports. Edited by Georgios A.

Megas. Athens, 77-87.

Dégh, Linda 1992. What kind of people tell legends? Folklore Processed in Honour of Lauri Honko on his 60th Birthday 6th March 1992. Edited by Reimund Kvideland. NIF Publications No. 24. Helsinki, 104-113.

Dégh, Linda and Vázsonyi, Andrew 1971. Legend and Belief. Genre. Vol. IV, Nr. 3, 281-304. Dégh, Linda and Vázsonyi, Andrew 1974. The Memorate and Proto-Memorate. Journal of American Folklore. Vol. 87. No. 345, 225-238.

Ellis, Bill 1989. When is Legend? An Essay in Legend Morphology. The Questing Beast.

Perspectives on Contemporary Legend. Volume IV. Edited by Gillian Bennett and Paul Smith.

Sheffield, 31-53.

E.R.A. blond kummitus. Omal ajal õnnetu armastuse pärast surnud parunipreili jalutuskäigud Eesti Rahvaluule Arhiivi ruumides. Tõelised tondilood muinasjuttude panipaigas? Vaba Maa, 1936. 03.02, nr 27.

Grider, Sylvia 1981. The Media Narraform: Symbiosis of Mass Media and Oral Tradition. $A R V$ 3, 125-131, 7.

Hiiemäe, Mall 1978. Kodavere pajatused. Tallinn.

Honko, Lauri 1964. Memorates and Study of Folk Belief. Journal of the Folklore Institute 1/2. Hague.

Klintberg, Bengt af 1989. Legends Today. Nordic Folklore. Recent Studies. Edited by Reimund Kvideland and Henning K. Sehmsdorf. Indiana University Press, 70-89.

Mitchell, Carol A. 1969. The White House. Indiana Folklore 2, 96-108.

Montell, William Lynwood 1992. Ghosts along the Cumberland. Deathlore in the Kentucky Foothills. University of the Tennessee Press. Knoxville.

Mullen, Patrick B. 1972. Modern Legend and Rumor Theory. Journal of the Folklore Institute 9, 95-109.

Noorhani, Piret, Saluvere, Tiina 1996. Ühest isevärki mängust. Mängult-päriselt. Tänapäeva folkloorist II. Toimetanud Mare Kõiva. Tartu, 26-38.

Pakalns, Guntis 1995. Ghost Narratives in Latvia - Changes during Recent Years. Foaftale News. No. 37, 1-3.

Päärt, Villu 1998. Tartus kummitavad nõiutud kuningatütar ja end üles poonud krahv. Tartu Postimees, 15. 02.

Randles, Jenny \& Hough, Peter 1998. Mõistatuslike nähtuste entsüklopeedia.

Smith, Paul 1989. Contemporary Legend: A Legendary Genre? Questing Beast. Perspectives on Contemporary Legend. Volume IV. Edited by Gillian Bennett and Paul Smith. Sheffield, 91101. 
Virtanen, Leea 1991. Kruununhaan kummitus. Kansan viisauden kirja. Porvoo, 414-415. Virtanen, Leea 1992. Have Ghosts Vanished with Industrialism? Folklore Processed in Honour of Lauri Honko on his 60th Birthday 6th March 1992. Edited by Reimund Kvideland. NIF Publications No. 24. Helsinki, 225-231.

Väljaots, Epp 1999. Igas kodus elab majavaim? Eesti Naine, 15-18.

Lisa 1

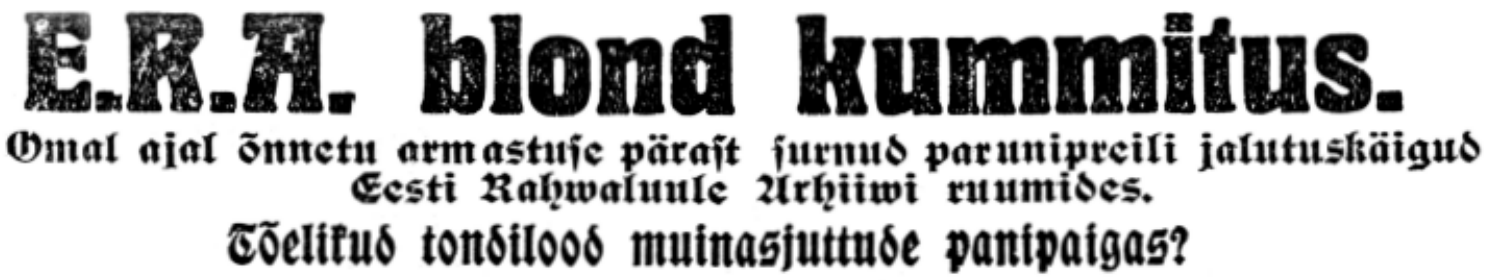

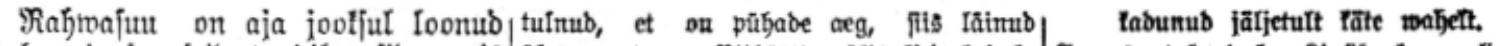

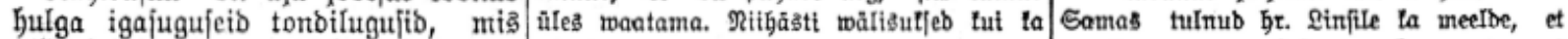
mõnelegi arawerelijele tananaha alnab olmb linni ja rumibeft pole ta teentia obe on brînett, huna nägemns

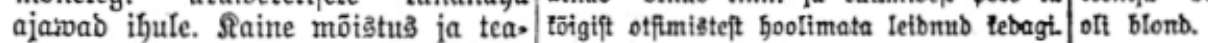

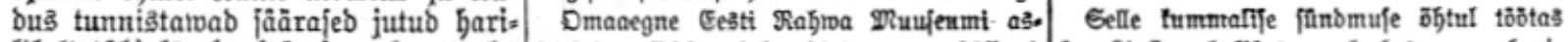

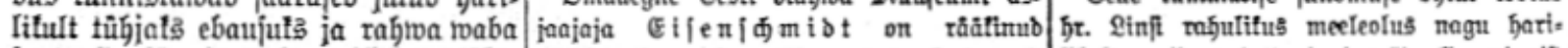

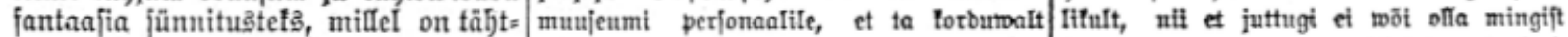

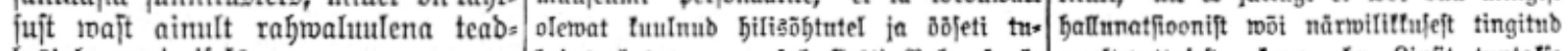

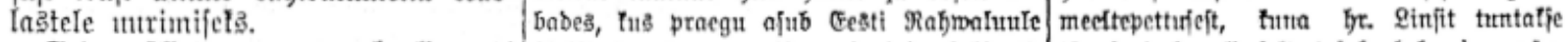

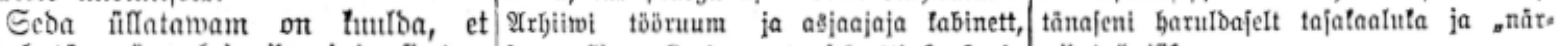
toecl tämapäcuvalgi riba inimeji teas jammujib. Sorb on ta jelgesti funimub, mibeta" ipituma.

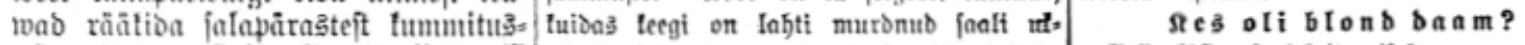

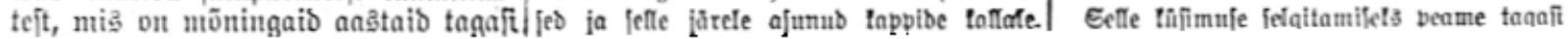

\section{Lisa 2}

Intervjuu Ernst Lintsiga.

Litereerinud E. Kalmre EKLA heliarhiivist fond KO HL 129, reg. 1979/47. Ernst Lintsit küsitlevad Rudolf Põldmäe (P) ja Ellen Liiv (E). E. Kalmre märkused nurksulgudes.

[Lintsi räägib Eesti Rahva Muuseumi loteriist.] ...10 000 raamatut. Siis oli kliente palju, kole töö.

P: Kole töö.

Vahel istusin kella üheteistkümneni teinekord. See õhtu, kui ma seda kummitust, ilusat daami nägin.

E: Seda me tahame küll kuulda, kuidas selle ilusa daamiga ikka oli.

[See ärgitus jääb pooleli, sest vahepeal tuleb jutuks siiski midagi muud.] 
[Siis Põldmäe küsib, miks Lintsi nii kaua poissmees on olnud, ja selle peale läheb jutt lõpuks kummitusenägemisele. Lintsi räägib sellest väga hea meelega, kuigi väidab mitu korda, et ei usu ja talle see lugu korda ei lähe.]

E: Aga kuidas selle Lilla Daamiga ikka oli? Kas ikka tõesti nägite?

P: No kuulame ära selle loo ka, see on küll rahvaluule natukene, aga...

Mina töötasin siin, see oli hiljem, venne aegu, see oli vist jah, see oli hiljem. Aga kõige rohkemb neid nägid...siin oli üks Int koristaja ja Eisenschmidt esi ja sis enne Kreissi oli üks Treiali-nimeline, tuu oli Ann [all?] ja too läks seetõttu siit ära, et nägi neid kummitusi nii palju. Ja sii Int, ole lahke, tema ütleb, et tõesti oli kummitus. Tema oli vist, meie all elas, seal kus see kantselei on.

\section{P: Keldris?}

Jah, ja vat ole lahke, kõnnib üks üleval. Ja temal oli üks õde, kes oli vallaline, ja tema mõtelnud, et oh sa pagan, tüdruk, et nüüd on mõne poisi siia sisse tullu. Joosep siia üles vaatama, mitte kedagi kuskilt, mitte kedagi. Eisenschmidtil oli varemalt niisugune lugu, et jooksis siit minema, jättis lahti ja ütles Indile, et mine vaatama, mis seal sünnib.

P: Kole lugu.

E: Aga kuidas ikka Lintsi ise sellega kokku sai?

Aga sis see tark [?] daam oli seal selles toas, kus see kaminaahi on. Ja kõige huvitavam on see lugu, et oli üks mees, kes rahukonverentsi ajal oli kokk, seal selles majas, kus oli see Rosenthali oma, endise Rü̈̈tli ja Küütri tänava nurgal, see suur maja mitmekõrdne. Te seda teate, ei tea?

P: Jah, aga mis sellega oli sis?

Seal oli see Okk [Vokk?] ja mina nägin teda sel ajal, kui rahukonverents käis. See ütles, ole lahke ja seal ilmus sellest daamist üks artikkel lehes "Rahva Hääl».

E: Kas sellel ajal «Rahva Hä̈̈l» oli?

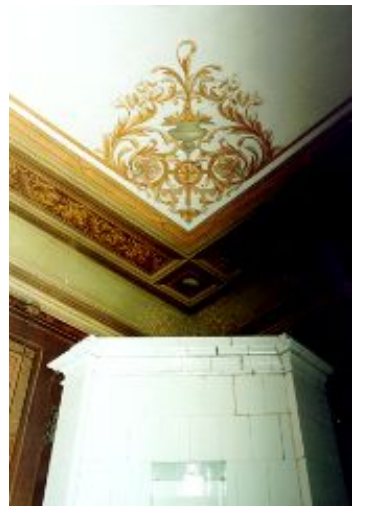

Mis? Oli «Rahva Hääl», jah. See peaks meie kogudes olema.

P: Kindlasti. Nojaa, aga kuidas Lintsi seda daami nägi siis? Palume. [Vahepeal tundub intonatsiooni järgi, et mõlemad intervjueerijad kahtlevad selle «Rahva Hääle» olemasolus.]

Mina mõtlen, et võibolla, et ma sel ajal olin ... olin nii ka segamini juba. Kell oli üheteistkümne ajal ôhtul, kui mina istusin seal selles ruumis, tegin tööd. Ja äkki, justnagu tuleks tuulevoog sealt kamina poolt ja mina vaatan ümber, et ilus väike daam. Ja kõige huvitavam see, et misukene see kleit seljas oli. Siin oli ristikheinalehed ja siin oli lilla [arusaamatu sõna, võis olla keep?] see pääl. Ja mina mõtlen, et pagana pihta, et aga see oli hilja, et tagasi tuli see Int mind välja laskma, ust kinni panema. Ja nüid ole lahke, ja tema [mõeldud see] daam oli niisugune ... mm töntsakas. Vaatan, et äkki tohoo, et mis see nüid on, ja käed laiali, oot-oot, et küll ma teen talle nüid hullu, käed laiali, ja kadus ära, ja see on oige, mina rohkem teda näinud ei ole. Ja tema on vist..., aga see Treial, see nägi... ma ei tea, mis siis see õieti nägi. Nad nägid kõik, aga mind ei huvitand see. Mina ei usu...

P: See oli see Helene Treial, kes abiellus selle keskarhiivi Varesega?

See jah. 
P: See hiljuti suri alles.

Ah ära suri?

P: Suri jah, Vares ka on surnud juba.

[Järgneb pikem jutt sellest, kes kõik veel surnud on.]

Tema pääle seda, kui Eisenschmidt ennast maha laskis, ei ole änämp. Ei ole olnud. Aga asi oli niimoodu, et kui mina selle, mis see pagan oli, selle kokale kõnelesin Toomepääl, misuke see daam välla nägi... Tuu ehmatas ära, karas püsti, et issand jumal, tuu on meie härra nooremb õde, kes ennast sinna nüid kamina tuas üles poos. Seepärast [et] see doktor Vaarend oli teda petnud. Vaarend elas seal üle, nü̈̈d on maha põlenud.

P: Aga kes see härra oli siis? See majaomanik, kelle sugulane ta oli siis, see daam?

See oli majaomaniku tütar.

P: Aga kes see majaomanik oli?

$\ddot{U} k s$ tsaari rittmeister.

Ega nime ei mäleta?

Tsaari rittmeister oli mü̈̈nud enne, kus see riigikohus sees oli, nüid see tööstuskool, müinud selle maja ära armee staabile 140000 vene kuldrubla eest. Ja sis oli ehitanud siia selle maja, aga siin läbikäiku veel ei olnud. Ja tema oli nii, mõtles väga rahus ela$d a$.

P: Aga selle maja oli ehitanud ju üks mõisnik?

Ei ole.

P: Groot, või kes? Ei, ma ei tea ka kindlasti, aga niisukesed jutud olid, et mõisnik ehitas.

Ei ole. Mis ta pagana nimi oli, kas ta mitte Groote ei olnud?

Võibolla jah.

E: Ja sis tema poeg oli selle Tartu rahu tegemise ajal siin?

Kelle poeg?

E: Ei no, aga kes see kokk, kellega te rääkisite, või oli ta sellel ajal olnud tema kokk?

See oli olnud kaheksa aastat tema kokk.

[Ernst Lintsi on intervjuu ajal 95-aastane ja tema jutust on kohati väga raske aru saada. Siiski on tunda, et kunagi on ta olnud päris hea jutustaja. Paljutki on ta selles loos ilmselt unustanud ja segamini ajanud, kuid üritab oma lugu rohkete pisiasjadega usutavamaks muuta.]

\section{Kommentaarid}

1. Pakutud näited on võetud artiklist «Igas kodus elab majavaim?» (Väljaots 1999).

2. Jutt on Hollywoodi menukast farsist «Ghostbusters». Sellest on tehtud nii multifilmi kui mängufilmi variant näitlejate Eddie Murphy ja Dan Ackroydiga peaosades. Nende 
tööks on kummitavate majade "puhastamine» vaimudest tänapäeva suurlinnas. Filmis loodud maailmas on kummitused midagi reaalset ja nende püüdjad populaarsed persoonid ühiskonnas, kes annavad intervjuusid, esinevad TV-s, raadios, peavad loenguid, kirjutavad raamatuid. Pakkudes turvalist meelelahutust ja serveerides üleloomulikke nähtusi kaasaegse elu loomuliku osana, tekitavad filmid vaatajas huvi kummitavate majade vastu ja toovad üleloomulikud nähtused vaatajale lähemale. (Vt Dégh 1992: 105). Filme on mitmel korral näidatud ka eesti telekanalites.

3. Kummitus- ja vaimukujutelm baseerub usundil, mis räägib inimhinge jätkuvast eksistentsist pärast surma. Kummituse visuaalseid stereotüüpe on kujundanud kirjandus. Gillian Bennett osutab sellele, et ebaloomuliku surma seostamine rahutu surnuga, kes hakkab hauast väljas käima, sai üldiseks alles 18. sajandil. Autor peab üheks sellise uskumise levimist soodustavaks teguriks vastavasisuliste rahvaraamatute võrdlemisi arvukat publitseerimist 19. sajandi teisel poolel. (Bennett 1999: 139-172).

4. Vt nt ka Leea Virtase lühiuurimust Helsingi kummitava maja kohta «Kruununhaan kummitus» (Virtanen 1991: 414-415). Traditsioonipäraselt võib eristada vähemalt kahte liiki vaimolendeid. Ühed rahutud surnud ilmutavad end sugulastele, tuttavatele jne. Nende ilmumine toimub tavaliselt piiratud ajal pärast surma ja nende rahustamiseks on võimalik kasutada tõrjemaagiat jms. Teistest kujuneb ehituse vaimolend, aardevalvur vms konkreetse kohaga seotud olend. Eesti traditsioonis on see nähtus sageli seotud vanade mõisate, losside või linnamajadega.

5. Materjal on litereeritult Eesti Rahvaluule Arhiivi kogus EFA I 40, lehekülgedel 1-42, artiklis on viidatud intervjuude numbritele.

6. Maja ajaloost vt Krista Aru artiklit «Kirjandusmuuseumi maja ja selle elanikud», Postimees, 26. nov. 1997.

7. Vt Aru 1997; Päärt 1998. Pärimuse järgi pidi enne «Vaba Maa» 1936. aasta artiklit olema ilmunud veel üks kirjutis. (Vt intervjuu nr 2). See väide ei ole aga siiani kinnitust leidnud.

8. Nuumen - mõiste mütoloogiast, mis tähendab isikustamata mütoloogilist jõudu.

9. Seda juhul, kui motiiviks lugeda seda, et Lilla Daam nõuab (mees)ohvreid.

10. Sks k Feinschmecker - maiasmokk.

11. Bennett väidab, et muistend on 'fikseeritav', kuid mitte kunagi 'fikseeritud', st muistendil kui zhanril ei olegi fikseeritud vormi. Muistendi teemad ja motiivid võivad ilmuda erinevates arutluse kontekstides, kohandades oma olekut ja struktuuri sellele vastavalt. Jutustamise loomulikus kontekstis eristab autor peale 'grupi saaga' ('Group Saga') veel meediapärast esitust (vt ka Grider 1981: 125-131), muistendipärast esitust, personaalkogemuse esitust. (Bennett 1989: 193-212).

12. Linda Dégh püüdis kaardistada kummitavaid maju Indianas ja sai hulgaliselt vastuseid igast soost ja vanusest inimestelt. Vastused sisaldasid väga detailseid kummituslugusid, mille juurde olid sageli joonistatud kummitavate kohtade täpsed plaanid, kuid enamasti ei olnud lisatud kirjutaja nime ega aadressi. (Vt Dégh 1992: 105-106).

13. Muuseumis on alati olnud öövalve. Sõjajärgsetel aastakümnetel pidi maja personal kordamööda andma puhkeöid valvurile. 1970.-80. aastatel oli personali kohuseks valvata maja riiklike pühade öödel.

14. Asuvad praegu omanike valduses. 